\title{
Summer- and Wintertime Variations of the Surface and Near-Surface Urban Heat Island in a Semiarid Environment ${ }^{\mathscr{D}}$
}

\author{
Francisco SALAmanca PAlOU AND Alex MAHAlov \\ School of Mathematical and Statistical Sciences, Julie Ann Wrigley Global Institute of Sustainability, and Urban \\ Climate Research Center, Arizona State University, Tempe, Arizona
}

(Manuscript received 15 March 2019, in final form 30 July 2019)

\begin{abstract}
This paper examines summer- and wintertime variations of the surface and near-surface urban heat island (UHI) for the Phoenix metropolitan area using the Moderate Resolution Imaging Spectroradiometer (MODIS), near-surface meteorological observations, and the Weather Research and Forecasting (WRF) Model during a 31-day summer- and a 31-day wintertime period. The surface UHI (defined based on the urban-rural land surface temperature difference) is found to be higher at night and during the warm season. On the other hand, the morning surface UHI is low and frequently exhibits an urban cool island that increases during the summertime period. Similarly, the near-surface UHI (defined based on the urban-rural 2-m air temperature difference) is higher at night and during summertime. On the other hand, the daytime nearsurface UHI is low but rarely exhibits an urban cool island. To evaluate the WRF Model's ability to reproduce the diurnal cycle of near-surface meteorology and surface skin temperature, two WRF Model experiments (one using the Bougeault and Lacarrere turbulent scheme and one with the Mellor-Yamada-Janjić turbulent parameterization) at high spatial resolution (1-km horizontal grid spacing) are conducted for each 31-day period. Modeled results show that the WRF Model (coupled to the Noah-MP land surface model) tends to underestimate to some extent surface skin temperature during daytime and overestimate nighttime values during the wintertime period. In the same way, the WRF Model tends to accurately reproduce the diurnal cycle of near-surface air temperature, including maximum and minimum temperatures, and wind speed during summertime, but notably overestimates nighttime near-surface air temperature during wintertime. This nighttime overestimation is especially remarkable with the Bougeault and Lacarrere turbulent scheme for both urban and rural areas.
\end{abstract}

\section{Introduction}

Currently, half of the world's population resides in urban areas, but it is expected that approximately six billion persons will live in cities by 2050 , which means around $66 \%$ of the global population will be urbanite by that time (United Nations, Department of Economic and Social Affairs Population Division 2015). To provide housing to the constantly growing urban population, vast extensions of natural landscapes are urbanized and integrated in complex networks to guarantee the supply of food, energy, and water to the new residents.

\footnotetext{
Supplemental information related to this paper is available at the Journals Online website: https://doi.org/10.1175/WAF-D-190054.s1.
}

Corresponding author: Francisco Salamanca Palou, fsalaman@ asu.edu
However, compared to native landscapes, buildings and pavements decrease the nocturnal cooling rates promoting a positive urban-rural near-surface air temperature difference, known as the urban heat island (UHI) effect, and modifying the weather and climate from local to global scales (e.g., Oke 1988; Oleson et al. 2010; Zhao and $\mathrm{Wu}$ 2017). The UHI phenomenon is the expression of a warmer city relative to its contiguous rural landscape, and its intensity is a complex function of urban morphology, anthropogenic heat emissions, and weather conditions. Future city residents could be exposed to considerable local warming forced by greenhouse gasinduced global climate change and severe UHIs owing to urban expansion (e.g., Georgescu et al. 2014; Salamanca et al. 2015; Tewari et al. 2017).

To minimize the expected adverse environmental impacts of urban growth and global warming (such as warmer temperatures and poorer air quality), it is fundamental to develop and evaluate mitigation and 
adaptation strategies by means of accurate predictive modeling tools that are able to quantify hydro-climatic impacts associated with the conversion of natural to urban landscapes. In this sense, the National Center for Atmospheric Research (in collaboration with research groups) developed and dynamically integrated a physics-based urban modeling system in the Weather Research and Forecasting (WRF) Model (Skamarock et al. 2008) as a community tool to tackle urban environmental issues (Chen et al. 2011). This WRF-urban modeling system consists of three urban canopy models (and one simple bulk urban parameterization) coupled to the Noah land surface model (Noah-LSM; Chen and Dudhia 2001) to parameterize urban surface processes. The most important role of a land surface model and/or an urban canopy model is to provide the lower boundary conditions for the coupled numerical weather prediction model. The coupling between the urban canopy models (UCMs) and Noah LSM in WRF is through the urban fraction parameter that specifies the fraction of manmade surfaces (i.e., buildings and pavements) present in an urban grid cell. Once the Noah LSM has computed the heat fluxes (and surface skin temperature) for the natural part and the UCM the corresponding heat fluxes for the man-made surfaces, the total gridscale surface sensible heat flux, for example, is estimated as the averaged value of both sensible heat fluxes weighted by their own partial coverage (for a complete description of the WRF-urban modeling system see Chen et al. 2011).

Many researchers have used the WRF-urban modeling system to project hydro-climatic impacts due to urban expansion and/or global warming and to develop and evaluate mitigation and adaptation strategies for urban environments at risk. For instance, Georgescu (2015), using the single-layer UCM (Kusaka and Kimura 2004) coupled to the Noah LSM, reported that summertime temperatures due to projected urban expansion by the end of this century for California (U.S.) would be $1^{\circ}-$ $2^{\circ} \mathrm{C}$ warmer than present-day summertime conditions. Similarly, Argüeso et al. (2014) evaluated the impact of projected urban expansion on near-surface air temperature for Sydney (Australia) under a future high greenhouse gas emission scenario. WRF simulations showed that global warming and urbanization in conjunction would increase minimum temperatures by $3.2^{\circ} \mathrm{C}$, whereas the average change due to global warming alone would be of $1.9^{\circ} \mathrm{C}$. More recently, Tewari et al. (2017), using the multilayer building energy model (MBEM; Martilli et al. 2002; Salamanca et al. 2011) integrated in the WRFurban modeling system, reported that (under the highest greenhouse gas emissions scenario) projected urban expansion for Arizona (United States) would increase summertime temperatures by $3.6^{\circ} \mathrm{C}$ for Phoenix and $3.1^{\circ} \mathrm{C}$ for Tucson metropolitan areas. Regarding development and evaluation of mitigation and adaptation strategies, for instance, Salamanca et al. (2016), using the MBEM coupled to the Noah LSM, demonstrated that large-scale deployment of rooftop solar photovoltaic panels for the two major cities of Arizona would reduce summertime near-surface temperatures across the diurnal cycle. Similarly, Vahmani et al. (2016), using the single-layer UCM, found that citywide adoption of cool roofs would reduce daytime warming by $0.9^{\circ} \mathrm{C}$ during summer in the Los Angeles and San Diego metropolitan areas. As a final example, Li et al. (2014), applying the single-layer UCM with a dynamically integrated green roof model over the Baltimore-Washington metropolitan area, demonstrated that green roofs with relatively abundant soil moisture have comparable effect in reducing the surface and near-surface UHIs to cool roofs under extreme heat weather conditions.

However, compared with the large number of applied studies, a smaller amount of investigations focus entirely on developing and/or evaluating the WRFurban modeling system. Recently, Salamanca et al. (2018) augmented the capabilities of the WRF-urban modeling system by coupling the three UCMs available in WRF, with the new community Noah with multiparameterization options (Noah-MP) land surface model (Noah-MP LSM; Niu et al. 2011; Yang et al. 2011). Unlike the Noah LSM, Noah-MP includes a dynamic vegetation model that allows computing the leaf area index and green vegetation fraction instead of taking prescribed values from a table and improves the major weaknesses of Noah LSM (for a complete description of the Noah-MP LSM see Niu et al. 2011). Conducting several WRF Model experiments at high spatial resolution (i.e., 1-km horizontal grid spacing) over the two most important cities of Arizona and during a two-week summertime period, Salamanca et al. (2018) demonstrated that Noah-MP reproduces better than Noah the daily evolution of near-surface meteorology and surface skin temperature and that MBEM coupled to Noah-MP is a promising physics-based predictive modeling tool for urban applications. Nevertheless, the authors never evaluated the NoahMP LSM's ability to reproduce the diurnal cycle of near-surface meteorology and surface skin temperature under wintertime weather conditions and neither the sensitivity of the results to the planetary boundary layer parameterization.

Therefore, the aim of this paper is twofold: on one hand, to examine summer- and wintertime variations of the surface and near-surface urban heat island for a semiarid urban environment using the Moderate 
TABLE 1. List of WRF Model experiments.

\begin{tabular}{lccc}
\hline \hline WRF experiments & $\begin{array}{c}\text { Land surface model } \\
(\text { sf_surface_physics }=4)\end{array}$ & $\begin{array}{c}\text { Planetary boundary layer } \\
\text { (bl_pbl_physics =2,8) }\end{array}$ & $\begin{array}{c}\text { Urban canopy model } \\
\text { (sf_urban_physics = 3) }\end{array}$ \\
\hline MP_PBL2 (summer) & Noah-MP & Mellor-Yamada-Janjić & MBEM \\
MP_PBL8 (summer) & Noah-MP & Bougeault and Lacarrere & MBEM \\
MP_PBL2 (winter) & Noah-MP & Mellor-Yamada-Janjić & MBEM \\
MP_PBL8 (winter) & Noah-MP & Bougeault and Lacarrere & MBEM \\
\hline
\end{tabular}

Resolution Imaging Spectroradiometer (MODIS) and near-surface meteorological observations, and on the other hand, to evaluate the WRF-urban modeling system's ability (specifically, the ability of MBEM coupled to the Noah-MP LSM) to reproduce the diurnal cycle of nearsurface meteorology and surface skin temperature during both summer- and wintertime weather conditions. The outline of this paper is as follows: methodology and numerical experiments are described in section 2 . The discussion of the results is presented in section 3 , and finally, conclusions are summarized in section 4 .

\section{Methodology}

\section{a. Data for WRF Model evaluation}

We use the nonhydrostatic (V3.7.1) version of the Weather Research and Forecasting (WRF) Model coupled to the Noah-MP LSM to reproduce the diurnal cycle of near-surface air temperature, wind speed, and surface skin temperature during a 31-day summer- and a 31-day wintertime period for the two most important cities of Arizona, that is, the Phoenix and Tucson metropolitan areas. The WRF Model's validation follows the same procedure as employed in Salamanca et al. (2018), and the next paragraph is derived from there with minor modifications. All WRF Model experiments are validated against eleven rural (Aguila, Bonita, Buckeye, Coolidge, Desert Ridge, Harquahala, Maricopa, Paloma, Payson, Queen Creek, and Roll) and four urban (Mesa, Phoenix Encanto, Phoenix Greenway, and Tucson) Arizona Meteorological Network (AZMET; $\mathrm{http} / / /$ cals.arizona.edu/azmet) surface weather stations for near-surface air temperature and wind speed at hourly rate (the location, elevation, and land use-land cover classification for the aforementioned fifteen AZMET surface weather stations is detailed in Table S1 in the online supplemental material). Specifically, WRFmodeled output is averaged over all rural and urban stations independently (considering the nearest grid point to station location), and compared with the corresponding averaged rural and urban observations (once every hour) during a 31-day summer- and a 31-day wintertime periods. In addition, WRF-modeled surface skin temperature is compared to daytime and nighttime MODIS land surface temperatures (specifically, we make use of the MODIS/Terra MOD11A1 and MODIS/Aqua MYD11A1 satellite products), which are available every day at approximately $1-\mathrm{km}$ spatial resolution (https://lpdaac.usgs.gov) and with an accuracy better than $1^{\circ} \mathrm{C}$ in the range from $-10^{\circ}$ to $50^{\circ} \mathrm{C}$ under clear sky conditions (e.g., Wan et al. 2004).

Finally, an urban domain (from $33.3^{\circ}$ to $33.4^{\circ} \mathrm{N}$ and from $112.0^{\circ}$ to $111.8^{\circ} \mathrm{W}$ ) of approximately $273 \mathrm{~km}^{2}$ surrounding Mesa weather station and a rural domain (from $33.45^{\circ}$ to $33.55^{\circ}$ and from $113.2^{\circ}$ to $113.0^{\circ} \mathrm{W}$ ) of the same extension surrounding Harquahala weather station are chosen for the characterization of the surface and near-surface urban heat island for Phoenix metropolitan area. The choice of Mesa and Harquahala was constrained by the need to have flat domains with uniform land use-land cover placed at similar height above sea level (see Table S1 for more details concerning both AZMET surface weather stations).

\section{b. WRF Model experiments}

Initially, we perform four high spatial resolution WRF Model experiments (see also section 3c), two covering the same 31-day summertime period from 1 June $(0000$ LT) to 1 July (2300 LT) 2012, and two covering the same 31-day wintertime period from 1 December (0000 LT) to 31 December (2300 LT) 2012 (see Table 1 for a complete description of the numerical experiments), to evaluate the WRF Model's ability to reproduce the diurnal cycle of near-surface meteorology and surface skin temperature under different weather conditions. Specifically, WRF-modeled near-surface air temperature (i.e., modeled $2-\mathrm{m}$ air temperature) and wind speed (i.e., modeled $10-\mathrm{m}$ wind speed) are compared against the corresponding averaged rural and urban observations once every hour. Additionally, WRFmodeled surface skin temperature is compared to MODIS/Terra and MODIS/Aqua land surface temperature observations, which are available every day around 1100 and $1300 \mathrm{LT}$, respectively, during daytime, and around 2200 and 0100 LT, respectively, during nighttime. All WRF Model experiments are performed with the multilayer building energy model (MBEM; 


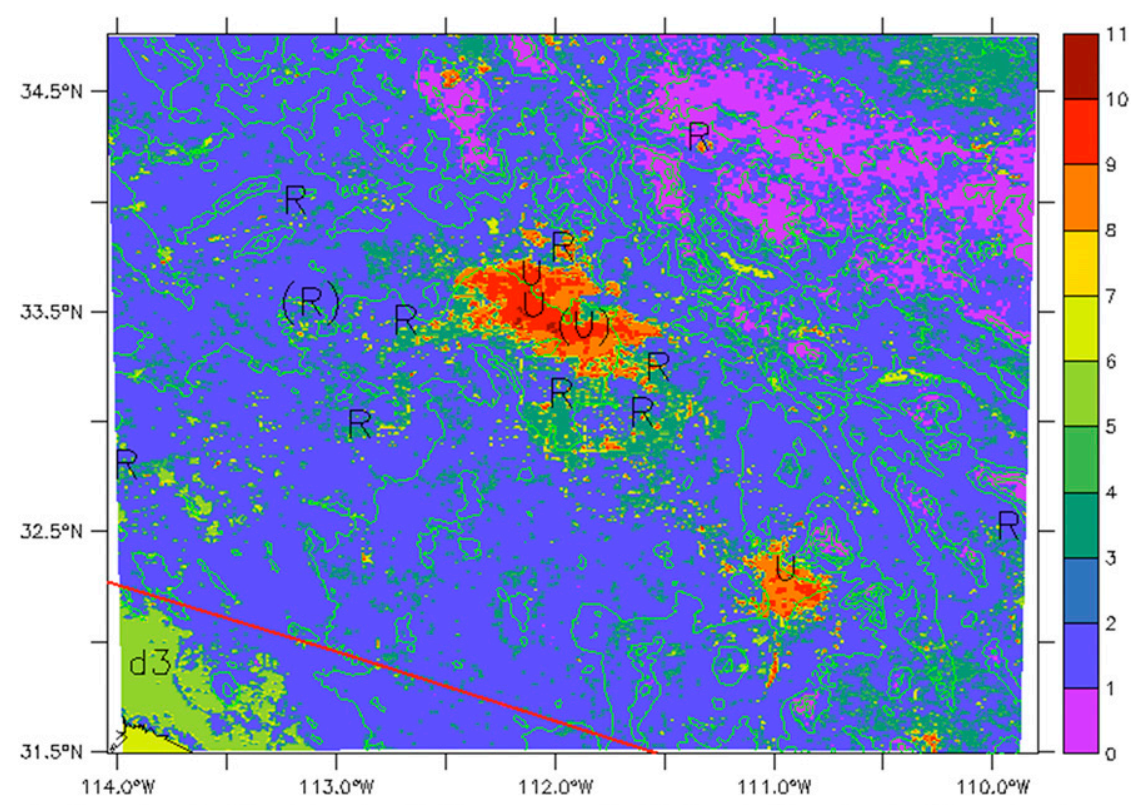

1: Forests, 2: Shrublands, 3: Savannas, 4: Wetlands/Croplands/Grasslands 5: Snow/Ice, 6: Barren/Sparsely vegetated, 7: Water, 8: Tundra

9: Urban (LIR), 10: Urban (HIR), 11: Urban (COI)

FIG. 1. MODIS-based land use-land cover (LULC) and urban classification (shaded based on Fry et al. 2011) for the inner domain. AZMET weather station locations for WRF Model evaluation are also indicated on the map including the terrain heights at intervals of $400 \mathrm{~m}$. Mesa and Harquahala weather stations are indicated between parentheses. LIR $=$ low intensity residential; HIR = high intensity residential; $\mathrm{COI}=$ commercial or industrial.

Martilli et al. 2002; Salamanca et al. 2011) coupled to the modern Noah-MP land surface model (Niu et al. 2011; Yang et al. 2011) to provide the lower boundary conditions for the coupled atmospheric WRF Model. That is, Noah-MP LSM is applied to the portion with natural cover and MBEM to the fraction with manmade surfaces in each numerical grid cell.

All WRF Model experiments have identical numerical domain, which consists of three two-way nested domains of $9-\mathrm{km}(276 \times 296), 3-\mathrm{km}(250 \times 283)$, and $1-\mathrm{km}$ $(391 \times 364)$ horizontal grid spacing, respectively. The vertical coordinate is divided in 40 eta levels, with 14 within the lowest $1.5 \mathrm{~km}$ to better characterize planetary boundary layer processes. The initial and boundary conditions required to drive WRF are provided by the National Centers for Environmental Prediction (NCEP) Final Analysis data files (number ds083.2), which are available every $6 \mathrm{~h}$ with a spatial resolution of $1^{\circ} \times 1^{\circ}$. The radiation transfer processes are parameterized with the Dudhia (1989) scheme for the shortwave and with the Rapid Radiative Transfer Model (Mlawer et al. 1997) for the longwave radiations. To evaluate the model's sensitivity to the planetary boundary layer parameterization, two WRF Model experiments (one for each 31-day period) are performed with the one-and-a-half-order closure Bougeault and Lacarrere (1989) turbulent scheme (hereafter denoted as MP_PBL8 simulations) and two (one for each 31-day period as well) with the two-order closure Mellor-YamadaJanjić (Janjić 1994) turbulent parameterization (henceforth denoted as MP_PBL2 experiments).

The urban landscape is characterized following the same technique as explained in Salamanca et al. (2018) and the next paragraph is also derived from there with minor changes. Urban areas are represented by means of three urban categories (viz., low-intensity and highintensity residential, and commercial or industrial) derived from the U.S. Geological Survey 30-m 2006 National Land Cover Dataset (Fry et al. 2011) in the inner domain, which includes the two most important cities of Arizona, that is, the Phoenix and Tucson metropolitan areas (see Fig. 1). Urban morphology parameters are extracted from Burian et al. (2002), who documented morphological characteristics for these three urban categories by analyzing an area around downtown Phoenix. Thermal properties for roofs, vertical walls, and roads are obtained from Clarke et al. (1991) and correspond to common building materials. The complete list of urban parameters used to drive the MBEM is detailed in Table S2. The nonurban land use 


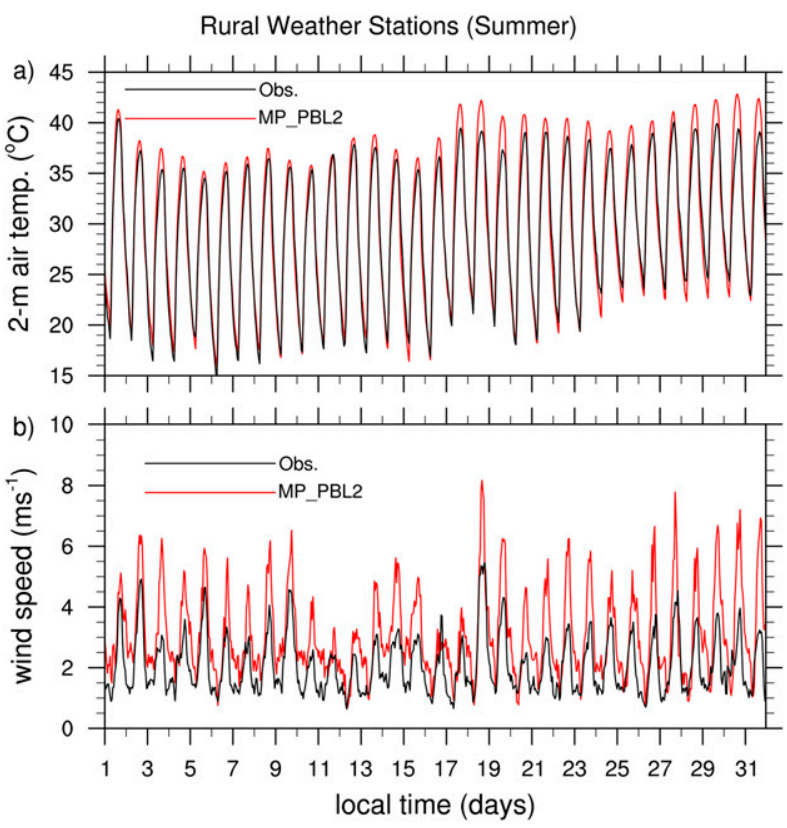

FIG. 2. (a) Time series of observed (black) and MP_PBL2modeled (red) 2-m air temperature $\left({ }^{\circ} \mathrm{C}\right)$ for the rural stations during the 31-day summertime period in 2012. (b) As in (a), but for the $10-\mathrm{m}$ wind speed $\left(\mathrm{m} \mathrm{s}^{-1}\right)$.

categories are characterized based on MODIS land cover classification.

\section{Results and discussion}

\section{a. Near-surface meteorology for rural areas}

In this section, we analyze the WRF Model's ability to reproduce the diurnal cycle of near-surface air temperature and wind speed for both summer- and wintertime periods for the rural areas. Figure 2 shows that MP_PBL2 experiment realistically captured the summertime daily evolution of near-surface air temperature, including maximum and minimum temperatures, and wind speed, although notably maximum winds were in some way overestimated. WRF-modeled root-meansquare error (RMSE) was $1.5^{\circ} \mathrm{C}$ for $2-\mathrm{m}$ air temperature and $1.3 \mathrm{~m} \mathrm{~s}^{-1}$ for $10-\mathrm{m}$ wind speed (see Table 2 for more details). Similarly, MP_PBL8 experiment reproduced realistically the summertime daily evolution of near-surface meteorology, although compared to the MP_PBL2 experiment; WRF-modeled root-mean-square errors were slightly larger (see Table 2 and Fig. S1 in the online supplemental material).

Figure 3 shows the wintertime daily evolution of MP_PBL2-modeled near-surface air temperature and wind speed against the corresponding rural observations. The MP_PBL2 experiment was able to capture the diurnal cycle of 2-m air temperature, although notably
TABLE 2. Root-mean-square error (RMSE) and mean absolute error (MAE) for WRF-modeled 2-m air temperature $\left({ }^{\circ} \mathrm{C}\right)$ and $10-\mathrm{m}$ wind speed $\left(\mathrm{m} \mathrm{s}^{-1}\right)$ against 11 AZMET rural weather stations.

\begin{tabular}{ccccc}
\hline $\begin{array}{c}\text { WRF } \\
\text { experiment }\end{array}$ & RMSE $\left({ }^{\circ} \mathrm{C}\right)$ & $\operatorname{MAE}\left({ }^{\circ} \mathrm{C}\right)$ & $\begin{array}{c}\text { RMSE } \\
\left(\mathrm{m} \mathrm{s}^{-1}\right)\end{array}$ & $\begin{array}{c}\text { MAE } \\
\left(\mathrm{m} \mathrm{s}^{-1}\right)\end{array}$ \\
\hline $\begin{array}{c}\text { MP_PBL2 } \\
\text { (summer) }\end{array}$ & 1.515 & 1.209 & 1.282 & 1.056 \\
$\begin{array}{c}\text { MP_PBL8 } \\
\text { (summer) }\end{array}$ & 1.813 & 1.497 & 1.336 & 1.066 \\
$\begin{array}{c}\text { MP_PBL2 } \\
\text { (winter) }\end{array}$ & 1.901 & 1.465 & 1.093 & 0.862 \\
$\begin{array}{c}\text { MP_PBL8 } \\
\text { (winter) }\end{array}$ & 2.387 & 1.883 & 1.480 & 1.135 \\
\hline
\end{tabular}

nighttime temperature was significantly overestimated during practically the first two weeks. On the other hand, the daily evolution of near-surface wind speed was accurately reproduced, including maximum and minimum winds, during the entire wintertime period. WRF-modeled RMSE was $1.9^{\circ} \mathrm{C}$ for 2-m air temperature and $1.1 \mathrm{~m} \mathrm{~s}^{-1}$ for $10-\mathrm{m}$ wind speed. Unlike the MP_PBL2 experiment, MP_PBL8 simulation overestimated nighttime near-surface air temperature during the entire month and WRF-modeled RMSE was increased up to $2.4^{\circ} \mathrm{C}$ (see Table 2 and Fig. S2 for more details). Similarly, the diurnal cycle of nearsurface wind speed was reasonably well captured, including maximum and minimum winds, although

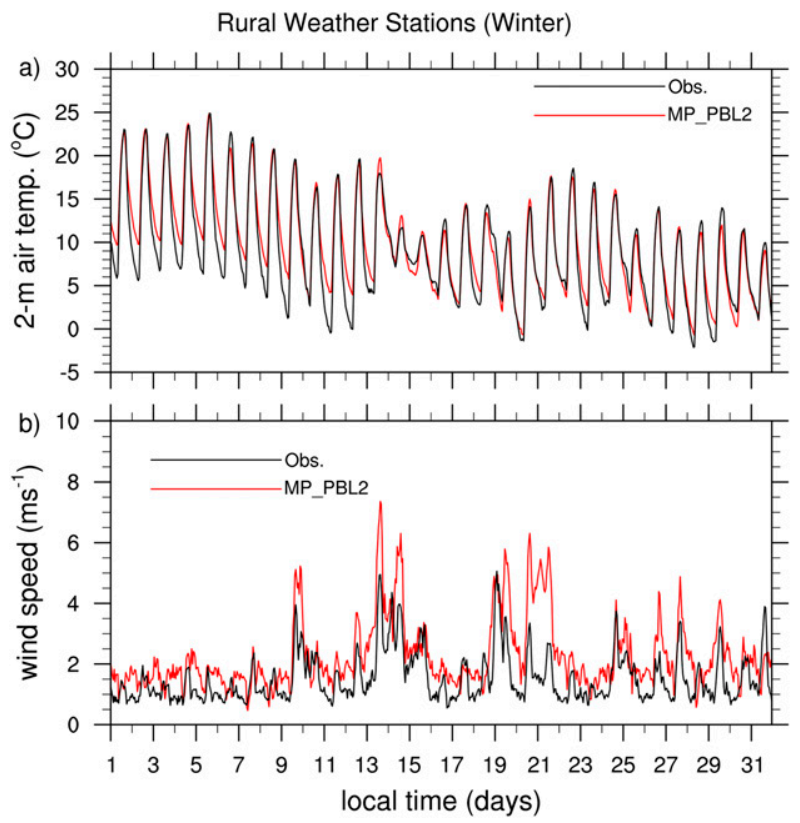

FIG. 3. (a) Time series of observed (black) and MP_PBL2modeled (red) 2-m air temperature $\left({ }^{\circ} \mathrm{C}\right)$ for the rural stations during the 31-day wintertime period in 2012. (b) As in (a), but for the $10-\mathrm{m}$ wind speed $\left(\mathrm{m} \mathrm{s}^{-1}\right)$. 


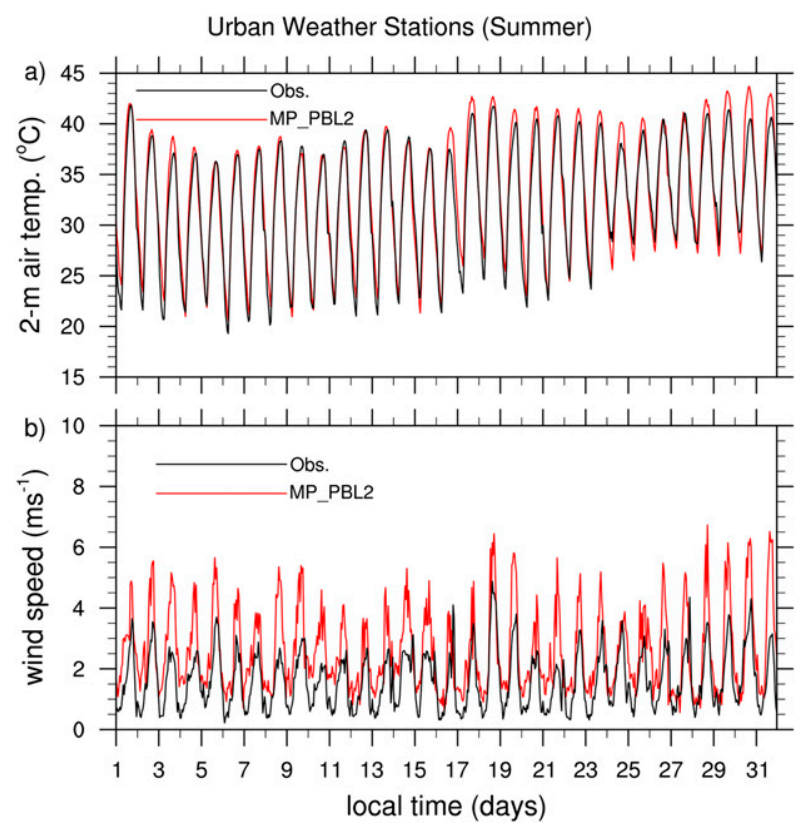

FIG. 4. (a) Time series of observed (black) and MP_PBL2modeled (red) 2-m air temperature $\left({ }^{\circ} \mathrm{C}\right.$ ) for the urban stations during the 31-day summertime period in 2012. (b) As in (a), but for the $10-\mathrm{m}$ wind speed $\left(\mathrm{m} \mathrm{s}^{-1}\right)$.

compared to the MP_PBL2 experiment; WRF-modeled RMSE was slightly larger (i.e., $1.5 \mathrm{~m} \mathrm{~s}^{-1}$ ). Based on these results reported for a semiarid environment and during a 31-day summer- and a 31-day wintertime periods, it can be stated that the MP_PBL2 experiment reproduces better than the MP_PBL8 experiment the daily evolution of near-surface air temperature and wind speed, although notably neither the MP_PBL2 nor MP_PBL8 experiments are able to reproduce accurately nighttime near-surface air temperature during wintertime.

\section{b. Near-surface meteorology for urban areas}

In this section, we analyze the WRF Model's ability to reproduce the diurnal cycle of near-surface air temperature and wind speed over the Phoenix and Tucson metropolitan areas for both summer- and wintertime periods. Figure 4 shows that the MP_PBL2 experiment accurately replicated the summertime daily evolution of 2-m air temperature, including maximum and minimum temperatures, and $10-\mathrm{m}$ wind speed, although maximum winds were to some extent overestimated. WRF-modeled root-mean-square errors were $1.5^{\circ} \mathrm{C}$ and $1.2 \mathrm{~m} \mathrm{~s}^{-1}$, respectively. Similarly, the MP_PBL8 experiment was able to reproduce realistically the diurnal cycle of near-surface air temperature and wind speed, although nighttime temperature was slightly overestimated compared to the MP_PBL2 experiment.
TABLE 3. RMSE and MAE for WRF-modeled 2-m air temperature $\left({ }^{\circ} \mathrm{C}\right)$ and $10-\mathrm{m}$ wind speed $\left(\mathrm{m} \mathrm{s}^{-1}\right)$ against four AZMET urban weather stations.

\begin{tabular}{ccccc}
\hline $\begin{array}{c}\text { WRF } \\
\text { experiment }\end{array}$ & $\mathrm{RMSE}\left({ }^{\circ} \mathrm{C}\right)$ & $\mathrm{MAE}\left({ }^{\circ} \mathrm{C}\right)$ & $\begin{array}{c}\mathrm{RMSE} \\
\left(\mathrm{m} \mathrm{s}^{-1}\right)\end{array}$ & $\begin{array}{c}\mathrm{MAE} \\
\left(\mathrm{m} \mathrm{s}^{-1}\right)\end{array}$ \\
\hline $\begin{array}{c}\text { MP_PBL2 } \\
\text { (summer) }\end{array}$ & 1.494 & 1.178 & 1.230 & 1.011 \\
$\begin{array}{c}\text { MP_PBL8 } \\
\text { (summer) }\end{array}$ & 2.345 & 1.932 & 1.372 & 1.143 \\
$\begin{array}{c}\text { MP_PBL2 } \\
\text { (winter) }\end{array}$ & 2.274 & 1.741 & 0.836 & 0.677 \\
$\begin{array}{c}\text { MP_PBL8 } \\
\text { (winter) }\end{array}$ & 3.090 & 2.518 & 1.106 & 0.885 \\
\hline
\end{tabular}

WRF-modeled RMSE was increased up to $2.3^{\circ} \mathrm{C}$ for near-surface air temperature and $1.4 \mathrm{~m} \mathrm{~s}^{-1}$ for wind speed (see Table 3 and Fig. S3 for more details).

Figure 5 shows that MP_PBL2 experiment reproduced realistically daytime 2-m air temperature but overestimated considerably nighttime temperature during almost the entire 31-day wintertime period. On the other hand, the diurnal cycle of near-surface wind speed, including maximum and minimum winds, was accurately replicated during the whole month. WRF-modeled root-mean-square errors were $2.3^{\circ} \mathrm{C}$ for near-surface air temperature and $0.8 \mathrm{~m} \mathrm{~s}^{-1}$ for wind speed. Figure S4 (see supplemental material) shows the corresponding results for the MP_PBL8 experiment.

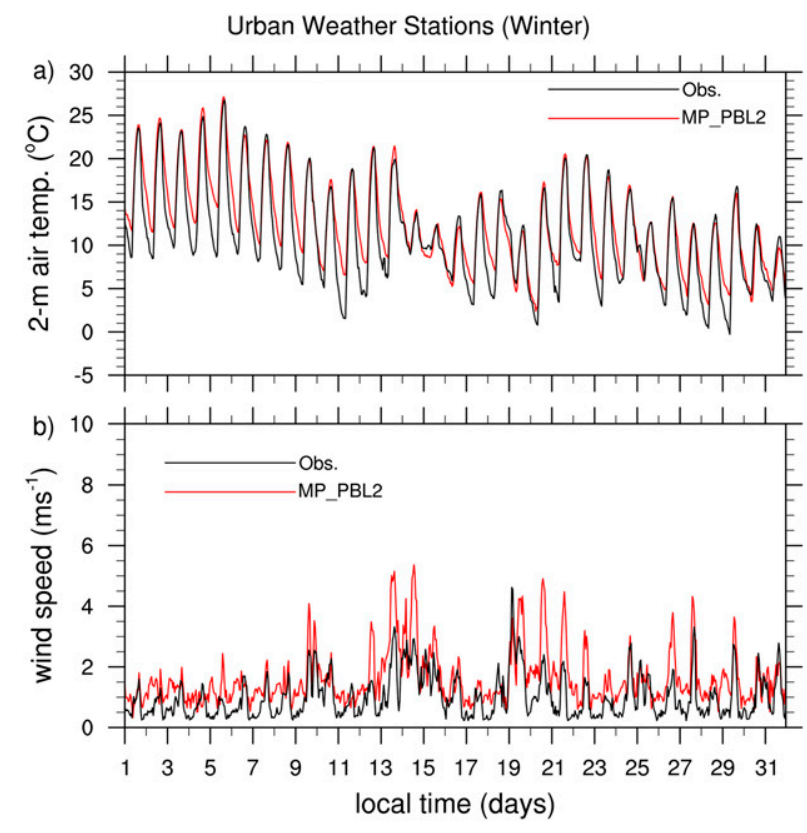

FIG. 5. (a) Time series of observed (black) and MP_PBL2modeled (red) 2-m air temperature $\left({ }^{\circ} \mathrm{C}\right.$ ) for the urban stations during the 31-day wintertime period in 2012. (b) As in (a), but for the $10-\mathrm{m}$ wind speed $\left(\mathrm{m} \mathrm{s}^{-1}\right)$. 

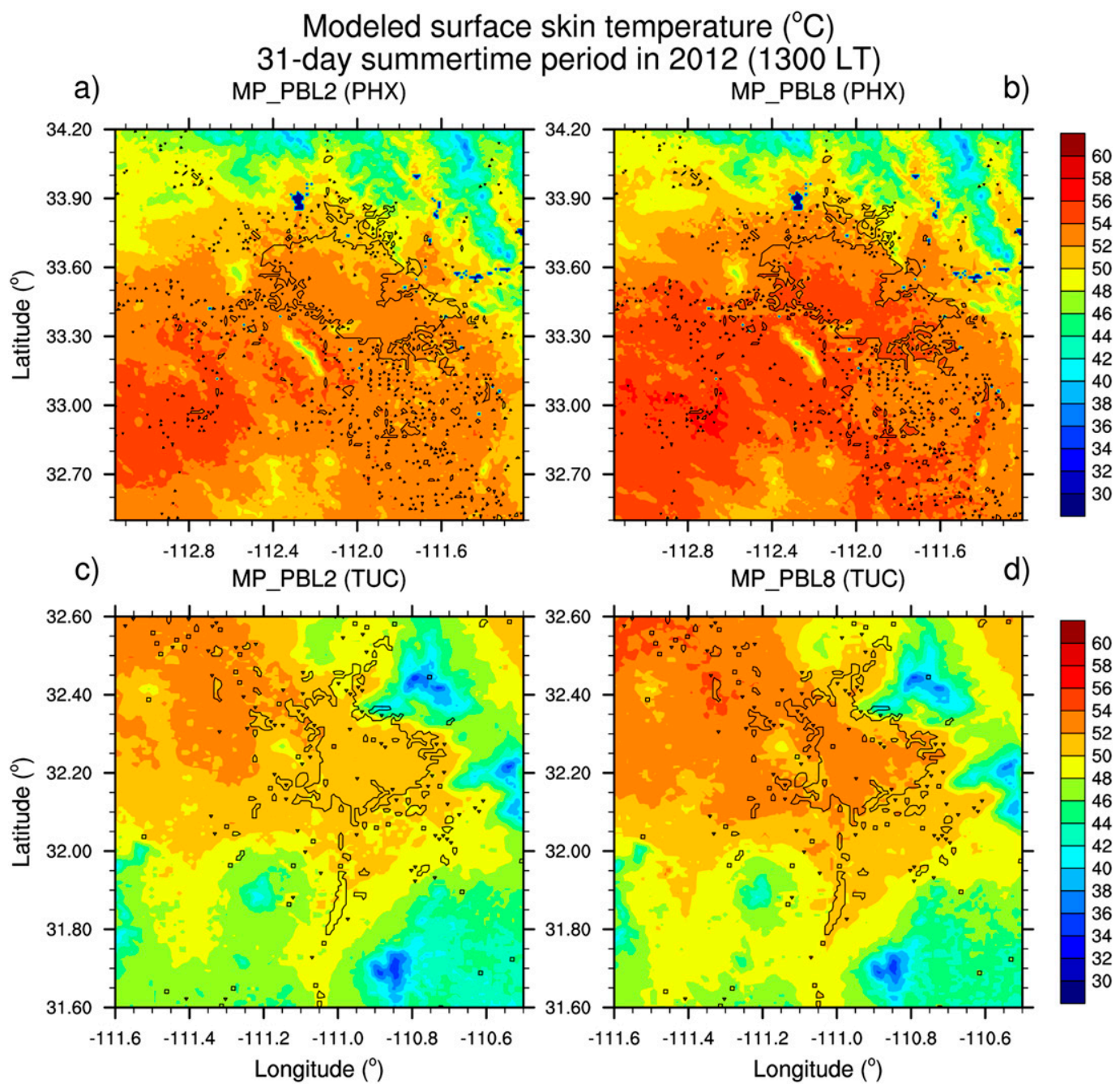

FIG. 6. (a) MP_PBL2 and (b) MP_PBL8 modeled mean surface skin temperature $\left({ }^{\circ} \mathrm{C}\right)$ averaged for the entire 31-day summertime period in June 2012 at 1300 LT and across the Phoenix region. (c) As in (a), but for the Tucson region. (d) As in (b), but for the Tucson region.

Similarly, near-surface nighttime temperature was significantly overestimated and WRF-modeled root-meansquare error was increased up to $3.1^{\circ} \mathrm{C}$ (see Table 3). On the other hand, the diurnal cycle of near-surface wind speed was accurately reproduced and WRF-modeled RMSE was $1.1 \mathrm{~m} \mathrm{~s}^{-1}$. Based on these results reported for Phoenix and Tucson metropolitan areas, it can be stated that MP_PBL2 experiment reproduces better than MP_PBL8 experiment the daily evolution of near-surface air temperature and wind speed, although notably both MP_PBL2 and MP_PBL8 experiments overestimate nighttime near-surface temperature during wintertime. Similarly, nighttime surface skin temperature was also overestimated for both urban and rural areas during the wintertime period (see section $3 \mathrm{~d}$ for more details).

\section{c. Sensitivity of near-surface air temperature to large-scale forcing}

To gain further insight into these results given that both the MP_PBL2 and MP_PBL8 experiments notably overestimated nighttime near-surface air temperature during wintertime, we repeated both WRF simulations but using a different large-scale meteorological forcing. This time NCEP North American Mesoscale (NAM) data files (number ds609.0), which are available with a spatial resolution of $12 \mathrm{~km}$ and every $6 \mathrm{~h}$ over continental U.S., provided the initial and boundary conditions for the 31-day wintertime period. It is noteworthy to mention that the nighttime surface skin temperature provided by NCEP NAM data files was considerably lower than the corresponding temperature provided 
TABLE 4. Spatial mean of daytime and nighttime MODIS-observed and WRF-modeled surface skin temperature $\left({ }^{\circ} \mathrm{C}\right)$ averaged for the entire 31-day summer and 31-day wintertime periods and across the Phoenix (PHX) and Tucson (TUC) regions.

\begin{tabular}{|c|c|c|c|c|c|c|c|c|}
\hline $\begin{array}{c}\text { WRF } \\
\text { experiment }\end{array}$ & $\begin{array}{c}\text { PHX } \\
(1100 \mathrm{LT})\end{array}$ & $\begin{array}{c}\text { TUC } \\
(1100 \mathrm{LT})\end{array}$ & $\begin{array}{c}\text { PHX } \\
(1300 \mathrm{LT})\end{array}$ & $\begin{array}{c}\text { TUC } \\
(1300 \mathrm{LT})\end{array}$ & $\begin{array}{c}\text { PHX } \\
(2200 \mathrm{LT})\end{array}$ & $\begin{array}{c}\text { TUC } \\
(2200 \mathrm{LT})\end{array}$ & $\begin{array}{c}\text { PHX } \\
(0100 \text { LT) }\end{array}$ & $\begin{array}{c}\text { TUC } \\
(0100 \text { LT) }\end{array}$ \\
\hline $\begin{array}{l}\text { MP_PBL2 } \\
\quad \text { (summer) }\end{array}$ & 47.807 & 45.594 & 51.150 & 48.456 & 25.379 & 23.184 & 21.573 & 19.207 \\
\hline $\begin{array}{l}\text { MP_PBL8 } \\
\text { (summer) }\end{array}$ & 48.653 & 46.252 & 52.096 & 49.428 & 26.437 & 24.094 & 22.445 & 19.899 \\
\hline $\begin{array}{l}\text { MODIS } \\
\quad \text { (summer) }\end{array}$ & 51.664 & 49.417 & 55.166 & 53.068 & 26.118 & 23.355 & 22.118 & 19.637 \\
\hline $\begin{array}{r}\text { MP_PBL2 } \\
\text { (winter) }\end{array}$ & 17.050 & 17.100 & 21.547 & 21.283 & 6.547 & 5.227 & 5.362 & 3.999 \\
\hline $\begin{array}{r}\text { MP_PBL8 } \\
\text { (winter) }\end{array}$ & 17.812 & 17.690 & 22.317 & 21.699 & 7.173 & 5.883 & 5.958 & 4.689 \\
\hline $\begin{array}{l}\text { MODIS } \\
\text { (winter) }\end{array}$ & 19.945 & 18.958 & 22.636 & 22.673 & 5.070 & 4.305 & 3.371 & 2.645 \\
\hline
\end{tabular}

by NCEP Final Analysis data files over Arizona (not shown). MP_PBL2-modeled RMSE for 2-m air temperature was reduced from $1.9^{\circ}$ to $1.6^{\circ} \mathrm{C}$ for the rural areas, and from $2.3^{\circ}$ to $2.1^{\circ} \mathrm{C}$ for the urban areas. Similarly, the MP_PBL8 experiment reduced the RMSE from $2.4^{\circ}$ to $1.9^{\circ} \mathrm{C}$ and from $3.1^{\circ}$ to $2.9^{\circ} \mathrm{C}$ for the rural and urban areas, respectively. Although both MP_PBL2 and MP_PBL8 experiments (driven with ds609.0 data files) improved to some extent the 2-m air temperature correspondence to observations, near-surface air temperature was still overestimated during nighttime, especially the 2-m air temperature modeled by MP_PBL8 experiment (see Figs. S5 and S6 for more details). Therefore, it can be stated that the nighttime nearsurface air temperature overestimation (during wintertime) is not a problem linked to the NCEP NAM or Final Analysis products; it is rather a weakness of the Noah-MP LSM (coupled to WRF) over semiarid environments. To preserve consistency between the summerand wintertime periods, all the results presented in the next sections are derived from the original WRF experiments forced with ds083.2 data files.

\section{d. Land surface temperature for the Phoenix and Tucson regions}

Here the WRF Model's ability to reproduce the diurnal cycle of surface skin temperature is evaluated for both summer- and wintertime periods. Specifically, WRF-modeled daytime (nighttime) surface skin temperature (averaged for the whole 31-day summer- and 31-day wintertime periods separately) is compared against the corresponding daily 31-day averaged daytime (nighttime) MODIS/Aqua and MODIS/Terra satellite observations retrieved at 1-km spatial resolution.

WRF-modeled surface skin temperature (at 1300 LT) across Phoenix (Figs. 6a,b) and Tucson (Figs. 6c,d) regions is shown in Fig. 6 for the summertime period.
Clearly, a little warmer surface skin temperature was simulated with the MP_PBL8 experiment $\left(52.1^{\circ}\right.$ and $\left.49.4^{\circ} \mathrm{C}\right)$ compared to the MP_PBL2 experiment $\left(51.2^{\circ}\right.$ and $48.5^{\circ} \mathrm{C}$ ) for both the Phoenix and Tucson regions, respectively (see Table 4 for more details). The MODIS land surface temperature averaged for the 31-day summertime period for both semiarid urban environments is shown in Figs. 7a and 7b. MODIS-observed spatial means aggregated across the Phoenix and Tucson regions were $55.2^{\circ}$ and $53.1^{\circ} \mathrm{C}$, respectively, which demonstrates that Noah-MP LSM (coupled to WRF) underestimates in some way the summertime maximum surface skin temperature. The same feature was modeled at 2200 LT, that is, MP_PBL2-modeled surface skin temperature was slightly lower $\left(25.4^{\circ}\right.$ and $23.2^{\circ} \mathrm{C}$ ) than the surface skin temperature modeled by MP_PBL8 experiment $\left(26.4^{\circ}\right.$ and $\left.24.1^{\circ} \mathrm{C}\right)$ for both the Phoenix and Tucson regions, respectively, although notably both WRF simulations reproduced accurately the observed nighttime land surface temperature retrieved by MODIS (see Table 4 and Fig. 8 for more details). MODIS-observed spatial means aggregated across the Phoenix and Tucson regions were $26.1^{\circ}$ and $23.4^{\circ} \mathrm{C}$, respectively, at this time of the night (see Figs. 7c and 7d for more details).

Finally, the WRF Model's ability to reproduce daytime and nighttime surface skin temperature is evaluated during the wintertime period. Modeled surface skin temperature (at $1300 \mathrm{LT}$ ) across the Phoenix and Tucson regions is shown in Fig. 9 for both WRF Model experiments. Like the summertime period, a little lower surface skin temperature $\left(21.5^{\circ}\right.$ and $\left.21.3^{\circ} \mathrm{C}\right)$ was simulated with the MP_PBL2 experiment compared to the MP_PBL8 experiment $\left(22.3^{\circ}\right.$ and $\left.21.7^{\circ} \mathrm{C}\right)$ for both the Phoenix and Tucson regions, respectively. MODIS land surface temperature averaged for the 31-day wintertime period for both semiarid urban environments is shown 
MODIS land surface temperature $\left({ }^{\circ} \mathrm{C}\right)$

a) 31-day summertime period in 2012 (1300 LT)

b)

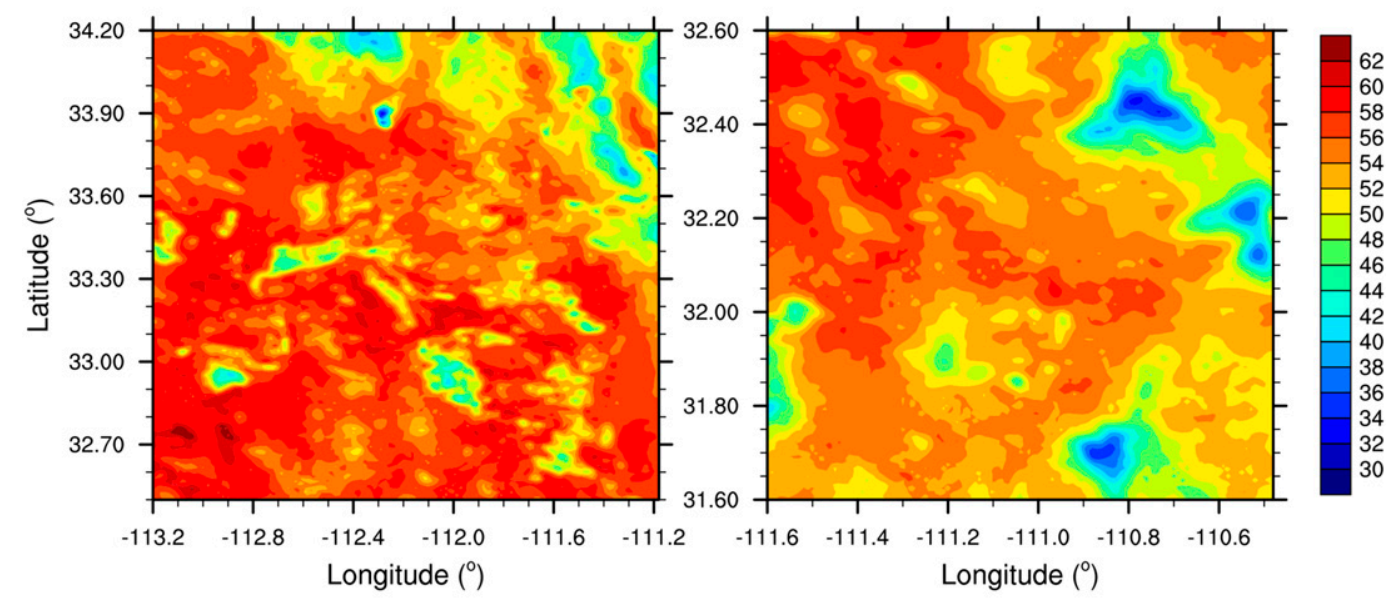

c)

31-day summertime period in 2012 (2200 LT)

d)

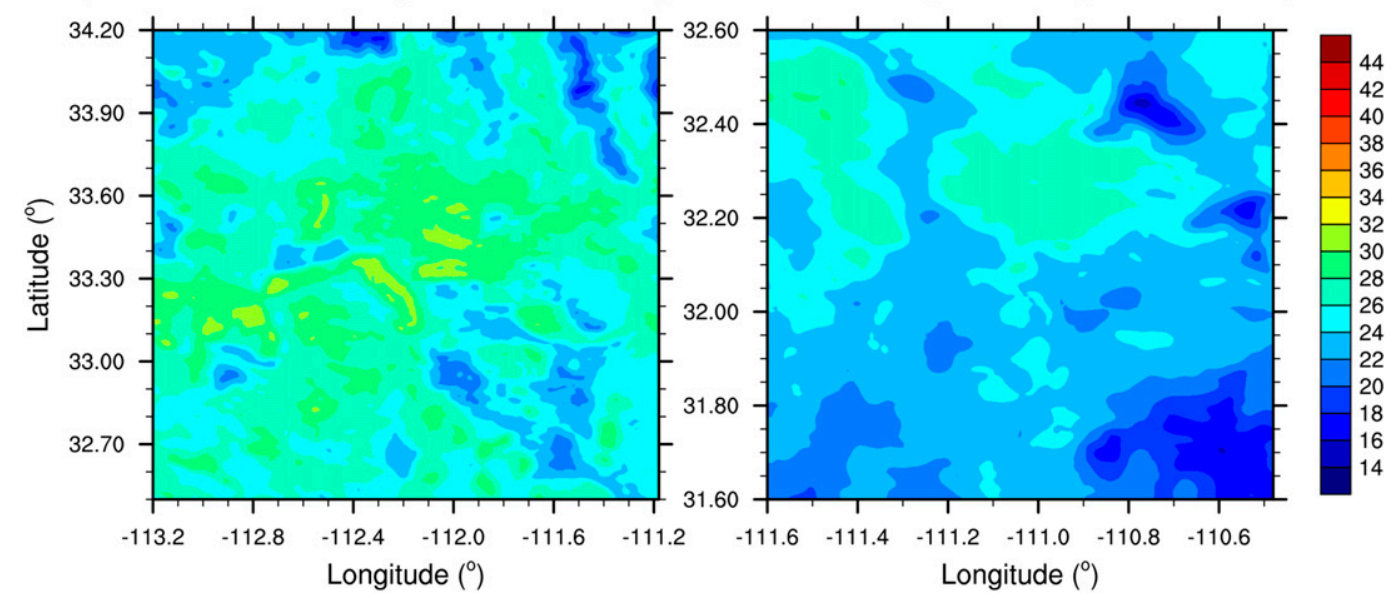

FIG. 7. (a),(b) Daytime MODIS/Aqua land surface temperature $\left({ }^{\circ} \mathrm{C}\right)$ averaged for the entire 31-day summertime period in 2012 and across the (left) Phoenix and (right) Tucson regions. (c),(d) As in (a) and (b), but for the nighttime MODIS/Terra land surface temperature $\left({ }^{\circ} \mathrm{C}\right)$.

in Figs. 10a and 10b. MODIS-observed spatial means aggregated across the Phoenix and Tucson regions were $22.6^{\circ}$ and $22.7^{\circ} \mathrm{C}$, respectively, which demonstrates that Noah-MP LSM underestimates in some way wintertime maximum surface skin temperature as well. Unlike the daytime, WRF-modeled nighttime surface skin temperature was warmer than the corresponding MODISobserved land surface temperature for both WRF Model experiments, although notably a lower warm bias was computed with the MP_PBL2 experiment. MP_PBL2-modeled surface skin temperature (at 2200 LT) was $6.5^{\circ} \mathrm{C}$ for Phoenix and $5.2^{\circ} \mathrm{C}$ for Tucson regions, while MP_PBL8-modeled surface skin temperatures were $7.2^{\circ}$ and $5.9^{\circ} \mathrm{C}$, respectively (see Table 4 and Fig. 11 for more details). MODIS-observed spatial means aggregated across the Phoenix and Tucson regions were $5.1^{\circ}$ and $4.3^{\circ} \mathrm{C}$, respectively, which demonstrates that Noah-MP LSM (coupled to WRF) overestimated nighttime surface skin temperature during wintertime (see Figs. 10c and 10d for more details). This nighttime overestimation was more prominent at 0100 LT (see Table 4 for more details).

Based on these results reported for a semiarid urban environment and for a 31-day summer- and a 31-day wintertime period, it can be stated that the WRF Model underestimates in some way maximum daytime surface skin temperature compared to MODIS-observed land surface temperature, although notably the MP_PBL8 experiment reduces the cold bias. On the other hand, the WRF Model tends to overestimate nighttime 

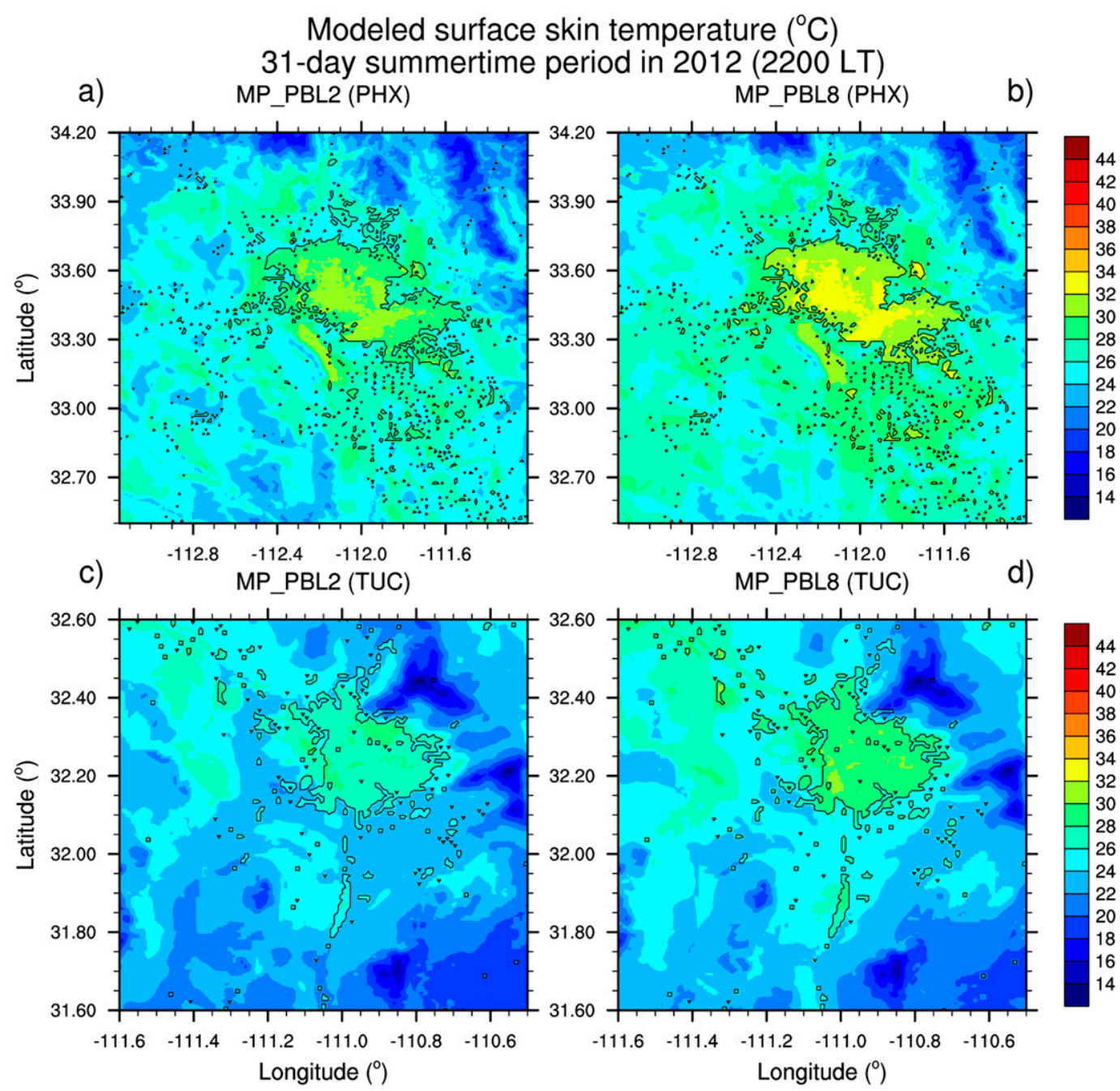

FIG. 8. (a) MP_PBL2 and (b) MP_PBL8 modeled mean surface skin temperature $\left({ }^{\circ} \mathrm{C}\right)$ averaged for the entire 31-day summertime period in June 2012 at 2200 LT and across the Phoenix region. (c) As in (a), but for the Tucson region. (d) As in (b), but for the Tucson region.

surface skin temperature during wintertime, given that both WRF Model experiments overestimated nighttime surface skin temperature during the wintertime period, although notably the MP_PBL2 experiment reduces the warm bias. This daily amplitude underestimation seems to be a common problem over semiarid environments and has been documented previously. For instance, Trigo et al. (2015) reported that ECMWFmodeled surface skin temperature presented a cool bias during daytime and a less pronounced warm bias during nighttime compared to MSG-observed land surface temperature (from Meteosat Second Generation) over most of Africa and Europe, but it was particularly pronounced over the semiarid regions of North Africa, Sahara, and Namibia. Additionally, they pointed out that an artificial reduction of the skin thermal conductivity was an effective way to partially correct the underestimation of the daily amplitude. We did not modify the skin thermal conductivity in our numerical experiments because the main goal of this study is to present the weak and strong points of the Noah-MP LSM (coupled to WRF) with the default setup and not to analyze the sensitivity of the results to different tuned parameters.

\section{e. Surface urban heat island for the Phoenix metropolitan area}

Summer- and wintertime daily variations of the nighttime surface UHI retrieved by MODIS/Terra and MODIS/Aqua satellite instruments and modeled by WRF are shown in Fig. 12 using 1-km spatial resolution data averaged over the urban (Mesa) and rural 


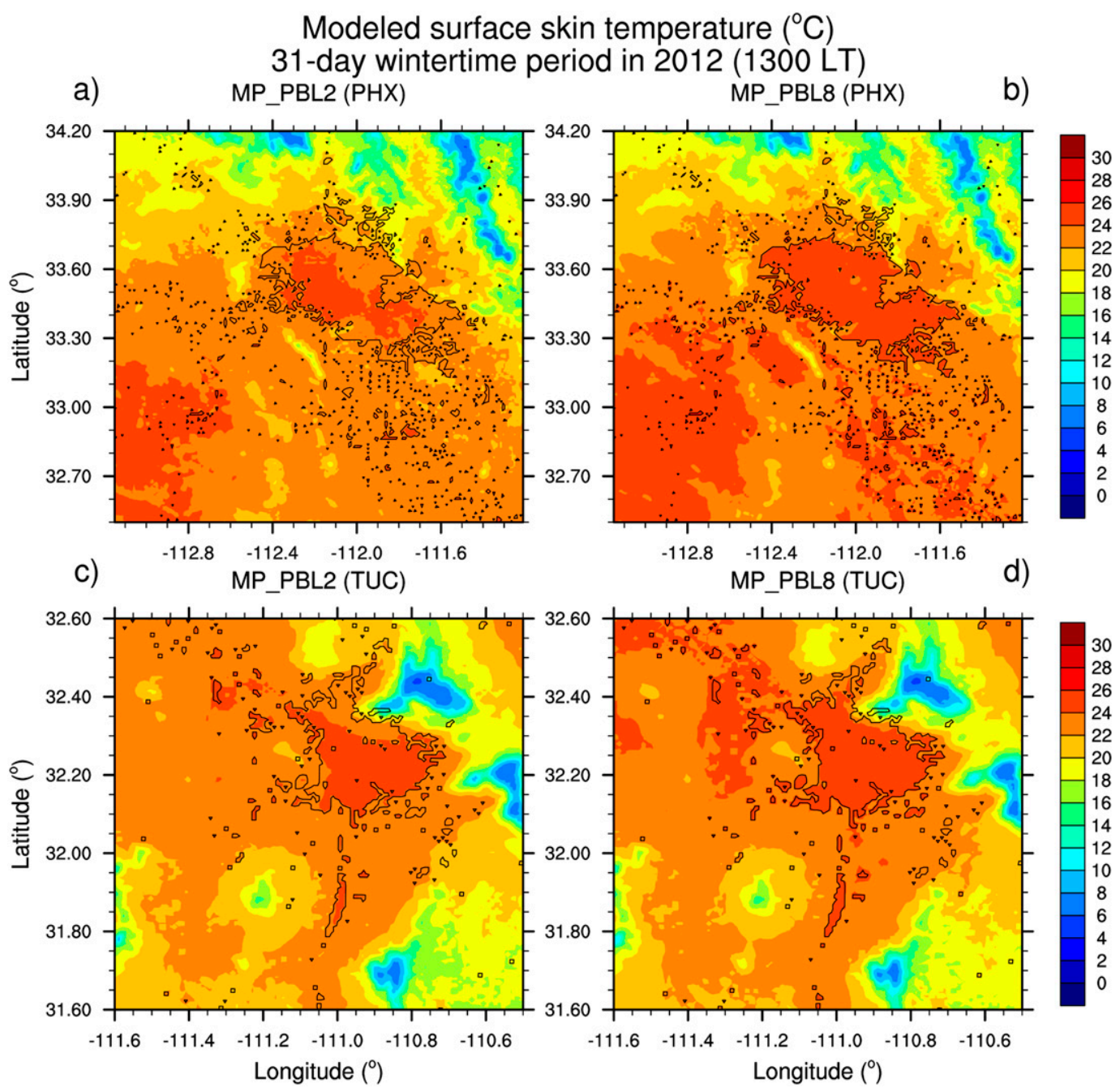

FIG. 9. (a) MP_PBL2 and (b) MP_PBL8 modeled mean surface skin temperature $\left({ }^{\circ} \mathrm{C}\right)$ averaged for the entire 31-day wintertime period in June 2012 at 1300 LT and across the Phoenix region. (c) As in (a), but for the Tucson region. (d) As in (b), but for the Tucson region.

(Harquahala) domains. MODIS detected a significant (31-day) mean nighttime surface UHI of $4.0^{\circ} \mathrm{C}$ (at 2200 LT) and $4.9^{\circ} \mathrm{C}$ (at $0100 \mathrm{LT}$ ) during the summertime period, but a considerably weaker nocturnal value of $2.6^{\circ}$ and $3.3^{\circ} \mathrm{C}$, respectively, during wintertime (see Table 5 for more details). Additionally, a negative (31-day) mean surface UHI for both summer- and wintertime periods was retrieved by MODIS (at 1100 LT), which demonstrates that the surrounding semiarid landscape of metro Phoenix warms at greater rates than the urban surface after sunrise. Recently, Chakraborty and Lee (2019), analyzing MODIS-observed land surface temperatures during a contemporary $15-\mathrm{yr}$ period, have demonstrated that cities in arid climates globally show a significant higher surface UHI during nighttime (compared to daytime), and that negative daytime values are common during January, June, October, and December months.

WRF Model experiments overestimated the nighttime surface UHI during summertime but underestimated its magnitude during the wintertime period. The MP_PBL2 experiment modeled a (31-day) mean surface UHI of $6.0^{\circ} \mathrm{C}$ at $2200 \mathrm{LT}$ and $5.4^{\circ} \mathrm{C}$ at $0100 \mathrm{LT}$ during summertime, while the MP_PBL8 experiment computed a value of $6.5^{\circ}$ and $6.1^{\circ} \mathrm{C}$, respectively. On the other hand, the MP_PBL2 experiment modeled a (31-day) mean surface UHI of $1.6^{\circ} \mathrm{C}$ at $2200 \mathrm{LT}$ and $1.5^{\circ} \mathrm{C}$ at $0100 \mathrm{LT}$ during wintertime, while the MP_PBL8 experiment simulated a magnitude of $1.8^{\circ}$ and $1.6^{\circ} \mathrm{C}$, respectively. Based on these results reported for the Phoenix metropolitan area, it can be stated that the WRF Model overestimates (underestimates) to some 

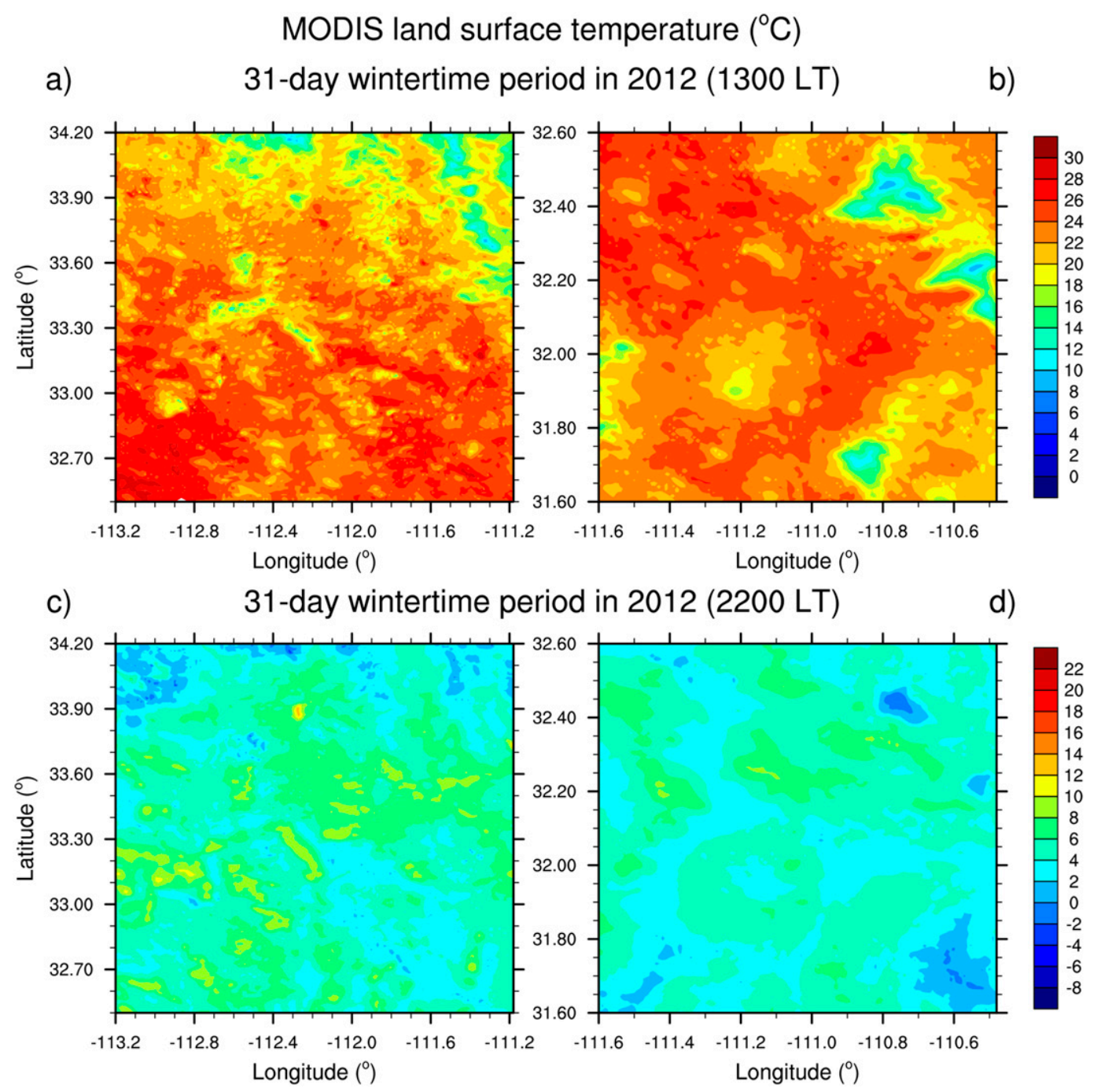

FIG. 10. (a),(b) Daytime MODIS/Aqua land surface temperature $\left({ }^{\circ} \mathrm{C}\right)$ averaged for the entire 31-day wintertime period in 2012 and across the (left) Phoenix and (right) Tucson regions. (c),(d) As in (a) and (b), but for the nighttime MODIS/Terra land surface temperature $\left({ }^{\circ} \mathrm{C}\right)$.

extent the nocturnal summertime (wintertime) surface UHI compared to MODIS observations. Furthermore, MODIS detected a clear morning surface urban cool island during both summer- and wintertime periods, which demonstrates that the semiarid landscape surrounding metro Phoenix warms at greater rates than the urban complex after sunrise, a statement reported previously for metro Phoenix during summer (see e.g., Georgescu et al. 2011) and for other metropolitan areas such as Mexico City (see e.g., Cui and De Foy 2012).

\section{f. Near-surface urban heat island for the Phoenix metropolitan area}

Last, we analyze the observed and WRF-modeled nighttime near-surface UHI for the Phoenix metropolitan area during the 31-day summer- and 31-day wintertime periods. Figure 13 shows the daily variations of nighttime near-surface UHI derived from Mesa (urban) and Harquahala (rural) weather stations and modeled by WRF using 2-m air temperature outputs averaged over the corresponding urban and rural domains. AZMET observations registered a large nighttime (31-day) mean near-surface UHI of $7.1^{\circ}$ (at $2200 \mathrm{LT}$ ) and $6.8^{\circ} \mathrm{C}$ (at 0100 LT) during the summertime period, but a significantly weaker nocturnal value of $3.8^{\circ}$ and $4.4^{\circ} \mathrm{C}$, respectively, during wintertime (see Table 6 for more details). Although a morning near-surface urban cool island was observed for some days, the (31-day) mean values (of near-surface UHI) were positive for both summer- and wintertime periods, which demonstrates that morning 


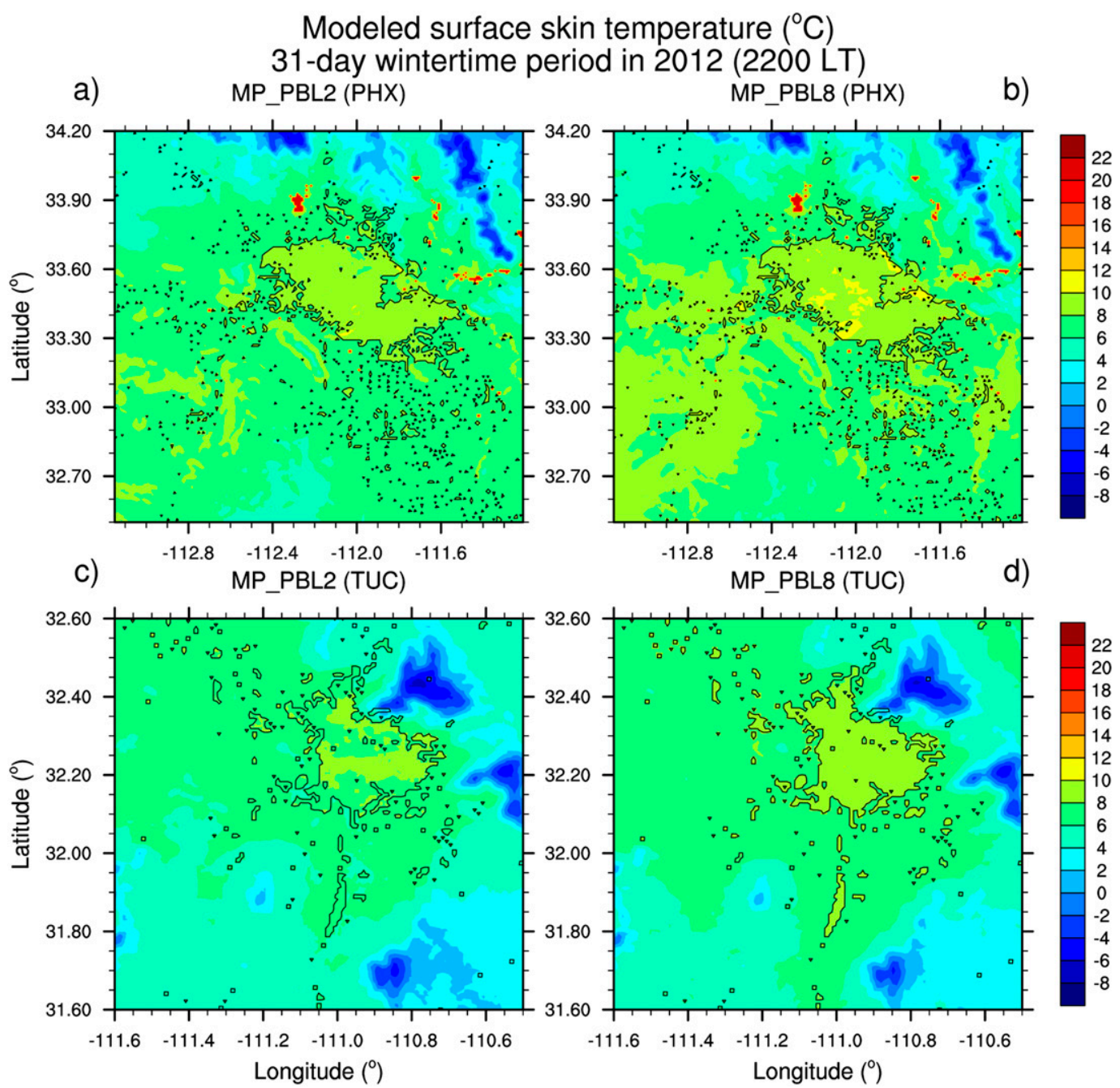

FIG. 11. (a) MP_PBL2 and (b) MP_PBL8 modeled mean surface skin temperature $\left({ }^{\circ} \mathrm{C}\right)$ averaged for the entire 31-day wintertime period in 2012 at 2200 LT and across the Phoenix region. (c) As in (a), but for the Tucson region. (d) As in (b), but for the Tucson region.

near-surface urban cool islands are not as common as morning surface urban cool islands in metro Phoenix.

Unlike the WRF-modeled nighttime surface UHI, WRF experiments underestimated nighttime near-surface UHI for both summer- and wintertime periods. The MP_PBL2 experiment computed a (31-day) mean nearsurface UHI of $5.8^{\circ}$ (at $2200 \mathrm{LT}$ ) and $4.8^{\circ} \mathrm{C}$ (at $0100 \mathrm{LT}$ ) during summertime, while the MP_PBL8 experiment simulated a magnitude of $5.9^{\circ}$ and $5.6^{\circ} \mathrm{C}$, respectively. On the other hand, the MP_PBL2 experiment computed a mean near-surface UHI of $2.1^{\circ} \mathrm{C}$ at $2200 \mathrm{LT}$ and $2.2^{\circ} \mathrm{C}$ at 0100 LT during wintertime, while the MP_PBL8 experiment simulated a value of $2.5^{\circ}$ and $2.4^{\circ} \mathrm{C}$, respectively. To gain further insight into these results, the averaged diurnal cycle of WRF-modeled and AZMETobserved near-surface UHIs for both summer- and wintertime periods are shown in Fig. 14. Clearly, the WRF Model was able to reproduce realistically the diurnal cycle of near-surface UHI during summertime, although notably its nighttime magnitude was slightly underestimated. On the other hand, during wintertime, neither the MP_PBL2 nor MP_PBL8 experiments were able to reproduce properly the diurnal cycle of nearsurface UHI. Based on these results reported for a semiarid urban environment and for a 31-day summerand a 31-day wintertime periods, it can be stated that the WRF Model underestimates in some way the nocturnal near-surface UHI during summertime but is not able to reproduce properly its diurnal cycle during wintertime compared to AZMET observations. Additionally, nocturnal near-surface UHI intensities show a strong daily variability in metro Phoenix, which has been 


\section{WRF-MODELED vs MODIS-OBSERVED SURFACE UHI $\left({ }^{\circ} \mathrm{C}\right)$}

a)

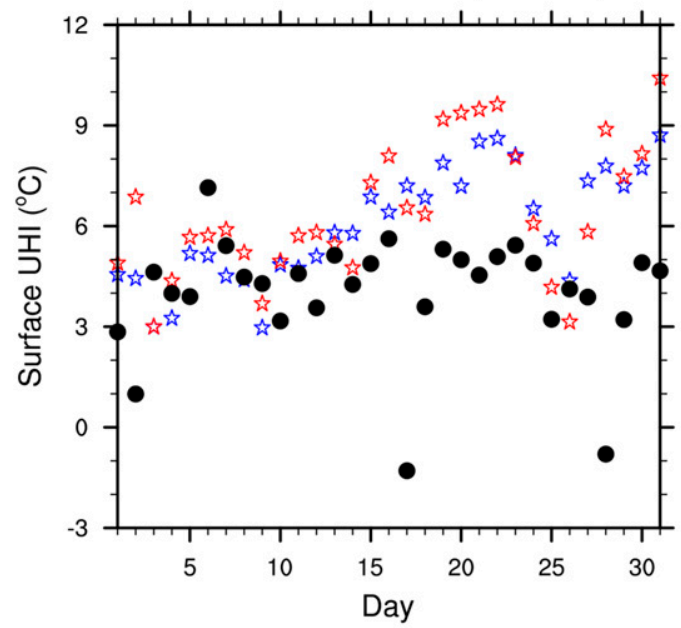

c)

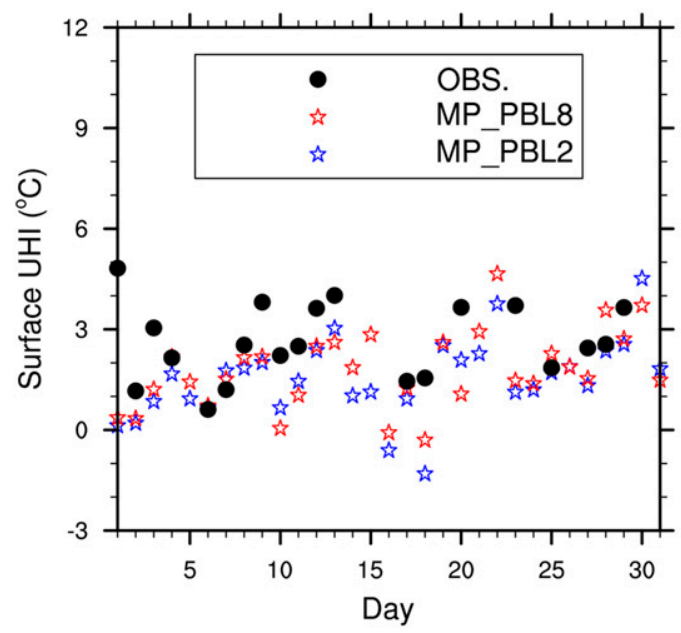

Summer Surface UHI (0100 LT)
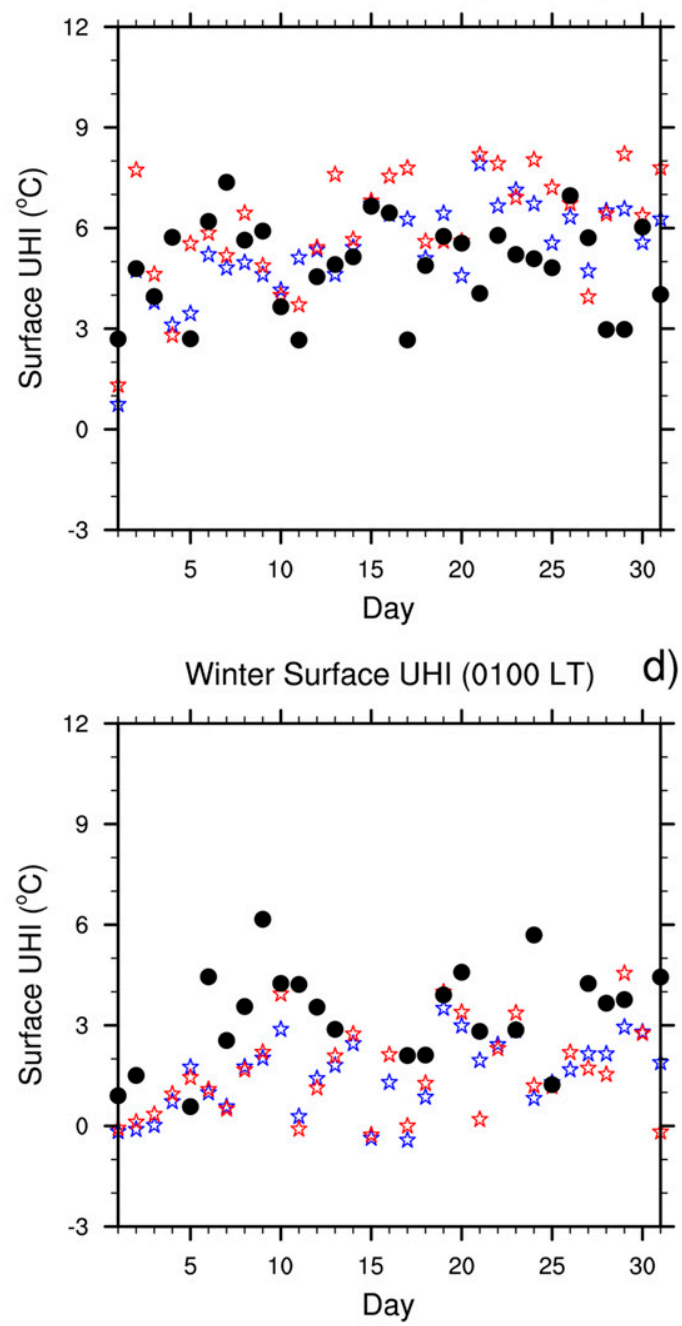

FIG. 12. (a),(b) Daily variations of nighttime MODIS-observed and WRF-modeled surface urban heat island $\left({ }^{\circ} \mathrm{C}\right)$ for the Phoenix metropolitan area during the 31-day summertime period in 2012 at (left) $2200 \mathrm{LT}$ and (right) 0100 LT. (c),(d) As in (a) and (b), but during the 31-day wintertime period in 2012.

reported previously using mobile transect techniques (see e.g., Sun et al. 2009).

\section{Summary and conclusions}

In this article, near-surface temperature recorded at several AZMET surface weather stations and land surface temperature estimated from MODIS/Terra and MODIS/Aqua satellite instruments are used to assess the WRF Model's ability (coupled to Noah-MP LSM) to reproduce the diurnal cycle of near-surface air temperature and surface skin temperature during a 31-day summer- and a 31-day wintertime periods over a semiarid urban environment. To evaluate the model's sensitivity to the planetary boundary layer parameterization, two WRF Model experiments are performed with the one-and-a-half-order closure Bougeault

TABLE 5. The 31-day mean nighttime MODIS-observed and WRF-modeled surface urban heat island $\left({ }^{\circ} \mathrm{C}\right)$ for the Phoenix metropolitan area during the summer- and wintertime periods.

\begin{tabular}{lcccc}
\hline $\begin{array}{c}\text { WRF } \\
\text { experiment }\end{array}$ & $\begin{array}{c}2200 \mathrm{LT} \\
\text { (summer) }\end{array}$ & $\begin{array}{c}0100 \mathrm{LT} \\
\text { (summer) }\end{array}$ & $\begin{array}{c}2200 \mathrm{LT} \\
\text { (winter) }\end{array}$ & $\begin{array}{c}\text { 0100 LT } \\
\text { (winter) }\end{array}$ \\
\hline MP_PBL2 & 6.044 & 5.363 & 1.567 & 1.546 \\
MP_PBL8 & 6.479 & 6.070 & 1.801 & 1.616 \\
MODIS & 4.022 & 4.887 & 2.628 & 3.305 \\
\hline
\end{tabular}




\section{WRF-MODELED vs OBSERVED NEAR-SURFACE UHI $\left({ }^{\circ} \mathrm{C}\right)$}

a)

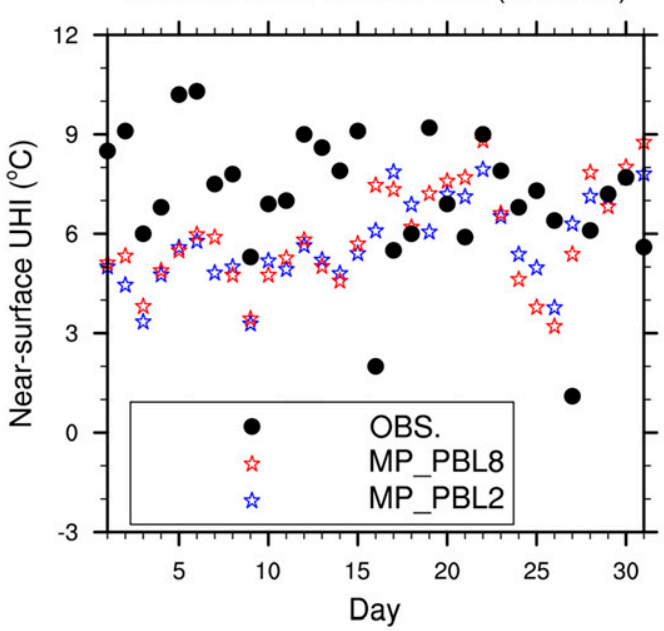

C) Winter Near-surface UHI (2200 LT)

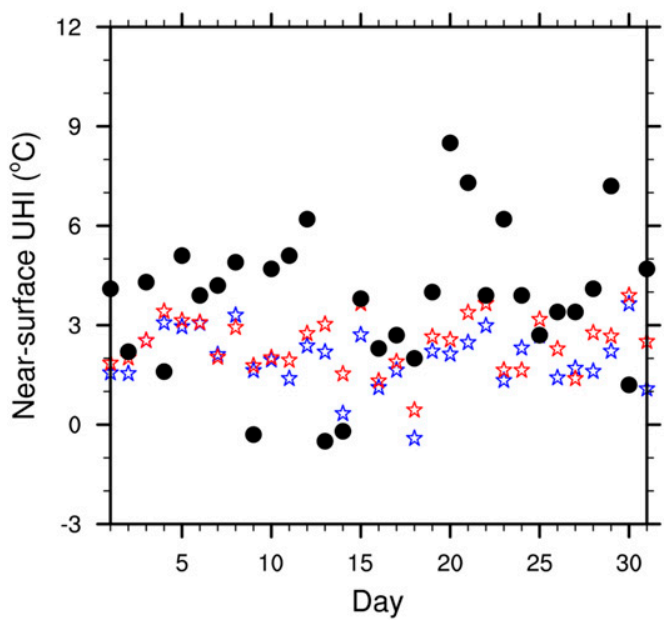

Summer Near-surface UHI (0100 LT)

b)

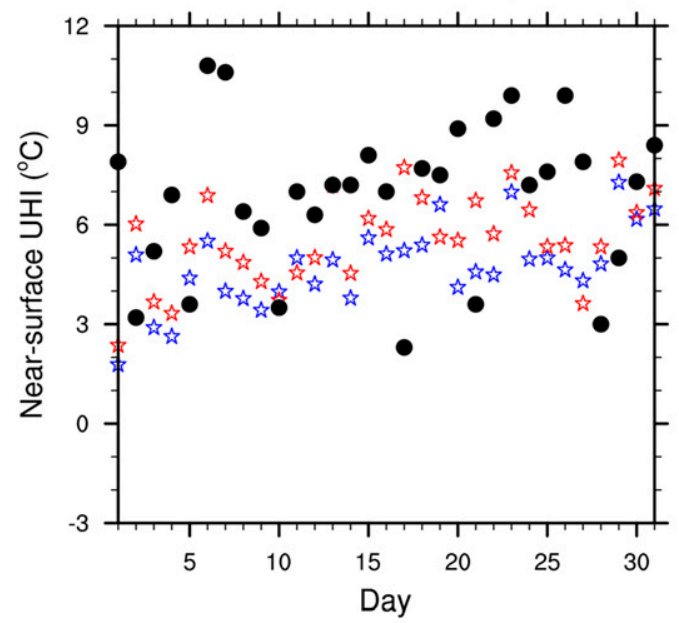

Winter Near-surface UHI (0100 LT) d)

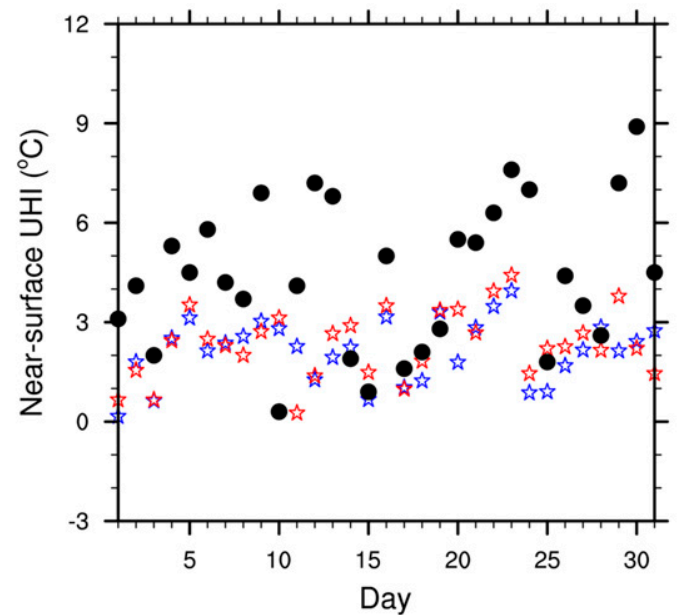

FIG. 13. (a),(b) Daily variations of nighttime AZMET-observed and WRF-modeled near-surface urban heat island $\left({ }^{\circ} \mathrm{C}\right)$ for Phoenix metropolitan area during the 31-day summertime period in 2012 at (left) $2200 \mathrm{LT}$ and (right) 0100 LT. (c),(d) As in (a) and (b), but during the 31-day wintertime period in 2012.

and Lacarrere (1989) turbulent scheme and two with the two-order closure Mellor-Yamada-Janjić (Janjić 1994) turbulent parameterization. Furthermore, summer- and wintertime variations of the surface and near-surface UHI for Phoenix metropolitan area are also investigated considering an urban domain of approximately $16.5 \mathrm{~km} \times 16.5 \mathrm{~km}$ surrounding Mesa and a rural domain of similar extension surrounding Harquahala surface weather stations. The main findings of this study can be summarized as follows:

1) The WRF Model tends to underestimate to some extent surface skin temperature during daytime and overestimate nighttime values during wintertime.
2) The WRF Model is able to accurately reproduce the diurnal cycle of near-surface air temperature, including maximum and minimum temperatures, and wind speed during summertime, but has a tendency to

TABLE 6. The 31-day mean nighttime AZMET-observed and WRF-modeled near-surface urban heat island $\left({ }^{\circ} \mathrm{C}\right)$ for the Phoenix metropolitan area during the summer- and wintertime periods.

\begin{tabular}{lcccc}
\hline \hline $\begin{array}{c}\text { WRF } \\
\text { experiment }\end{array}$ & $\begin{array}{c}\text { 2200 LT } \\
\text { (summer) }\end{array}$ & $\begin{array}{c}\text { 0100 LT } \\
\text { (summer) }\end{array}$ & $\begin{array}{c}\text { 2200 LT } \\
\text { (winter) }\end{array}$ & $\begin{array}{c}\text { 0100 LT } \\
\text { (winter) }\end{array}$ \\
\hline MP_PBL2 & 5.795 & 4.770 & 2.052 & 2.155 \\
MP_PBL8 & 5.930 & 5.579 & 2.463 & 2.360 \\
AZMET & 7.116 & 6.845 & 3.761 & 4.419 \\
\hline
\end{tabular}



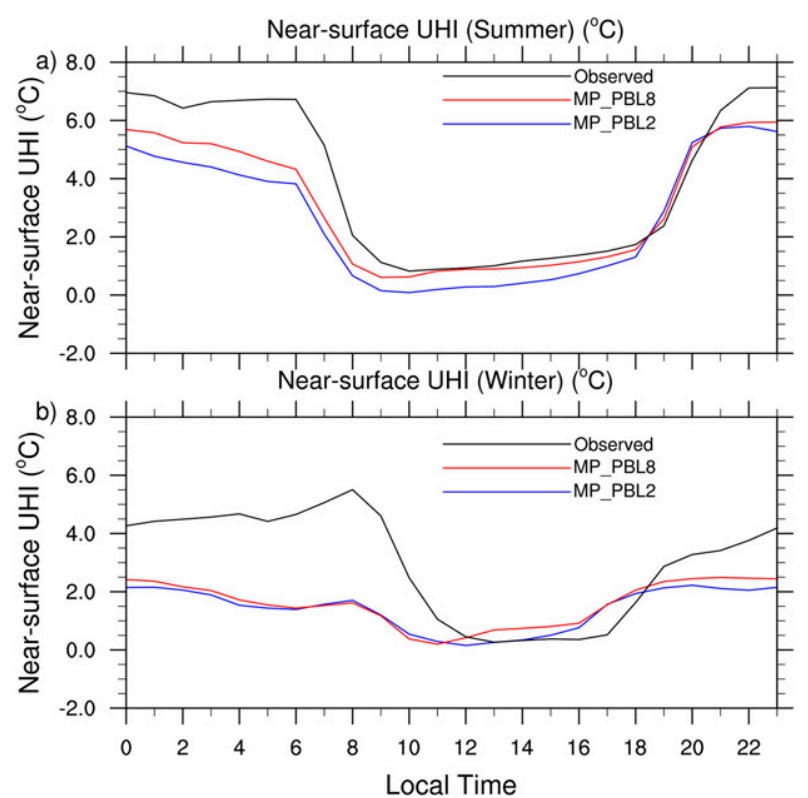

FIG. 14. (a) Averaged diurnal cycle of AZMET-observed and WRF-modeled near-surface urban heat island $\left({ }^{\circ} \mathrm{C}\right)$ for the Phoenix metropolitan area for the entire 31-day summertime period in 2012. (b) As in (a), but for the entire 31-day wintertime period in 2012.

overestimate nighttime near-surface air temperature during wintertime.

3) The surface UHI in metro Phoenix is found to be higher at night and during summertime with a maximum (31-day) mean value of $4.9^{\circ} \mathrm{C}$ detected by MODIS/Aqua at $0100 \mathrm{LT}$. On the other hand, morning surface UHI is low and frequently exhibits an urban cool island that increases during the warm season.

4) The near-surface UHI is also higher at night and during summertime with a maximum (31-day) mean value of $7.1^{\circ} \mathrm{C}$ recorded at $2200 \mathrm{LT}$. On the other hand, daytime near-surface UHI is low but rarely exhibits an urban cool island.

5) The WRF Model tends to overestimate nighttime surface UHI during summertime (modeled mean values were $0.5^{\circ}$ and $1.2^{\circ} \mathrm{C}$ larger than MODISobserved values at $0100 \mathrm{LT}$ ), but underestimate its magnitude (modeled mean values were $1.7^{\circ}$ and $1.8^{\circ} \mathrm{C}$ lower than MODIS-estimated values at 0100 LT) during the wintertime period.

6) The WRF Model is able to reproduce realistically the diurnal cycle of near-surface UHI during summertime, although notably its nighttime magnitude was underestimated by $1.2^{\circ}-1.3^{\circ} \mathrm{C}$ at $2200 \mathrm{LT}$. On the other hand, during wintertime, WRF-experiments are not able to reproduce properly the diurnal cycle of near-surface UHI.
Although the Noah-MP LSM (coupled to WRF) has been evaluated several times under different scenarios and weather conditions (e.g., Niu et al. 2011; Yang et al. 2011; Barlage et al. 2016; Salamanca et al. 2018), the present study demonstrates that more numerical experiments at high spatial resolution (i.e., 1-km horizontal grid spacing) are needed in light of improving the land surface model's performance given that Noah-MP was developed to improve the major weaknesses of Noah LSM and to be the default WRF LSM option. Land surface temperature is key for correctly representing the diurnal cycle of nearsurface meteorology (and climatology) and its evaluation against satellite observations should be included more often in modeling studies. As a final remark, we end by pointing out that these results have been obtained during a summer- and a wintertime periods over a semiarid urban environment and should not be extrapolated to other seasons or to other nonsemiarid biomes.

Acknowledgments. The MYD11A1 and MOD11A1 products were retrieved from the online Data Pool, courtesy of the NASA EOSDIS Land Processes Distributed Active Archive Center (LP DAAC), USGS/Earth Resources Observation and Science (EROS) Center, Sioux Falls, South Dakota, (https:// e4ft101.cr.usgs.gov/MOLT/). We would like to acknowledge high-performance support from Cheyenne (doi: 10.5065/D6RX99HX) provided by NCAR's Computational and Information Systems Laboratory, sponsored by the National Science Foundation. NSF DMS 1419593 and USDA NIFA 2015-67003-23508 grants have funded this work. WRF-modeled output data used in this article are stored at ASU's High-Performance Computing facilities (https://cores/research.asu.edu/research-computing/ about) and can be available to anyone upon request. Finally, we thank the anonymous reviewers for their valuable comments, which helped to improve this manuscript.

\section{REFERENCES}

Argüeso, D., J. P. Evans, L. Fita, and K. J. Bormann, 2014: Temperature response to future urbanization and climate change. Climate Dyn., 42, 2183-2199, https://doi.org/10.1007/ s00382-013-1789-6.

Barlage, M., S. Miao, and F. Chen, 2016: Impacts of physics parameterizations on high-resolution weather prediction over two Chinese megacities. J. Geophys. Res. Atmos., 121, 44874498, https://doi.org/10.1002/2015JD024450.

Bougeault, P., and P. Lacarrere, 1989: Parameterization of orographyinduced turbulence in a mesobeta-scale model. Mon. Wea. Rev., 117, 1872-1890, https://doi.org/10.1175/1520-0493(1989) 117<1872:POOITI $>2.0$.CO;2.

Burian, S. J., S. P. Velugubantla, and M. J. Brown, 2002: Morphological analyses using 3D building databases. Tech. Rep. LA-UR-02-6726, Los Alamos National Laboratory, 65 pp. 
Chakraborty, T., and X. Lee, 2019: A simplified urban-extent algorithm to characterize surface urban heat islands on a global scale and examine vegetation control on their spatiotemporal variability. Int. J. Appl. Earth Obs. Geoinfo., 74, 269-280, https://doi.org/10.1016/j.jag.2018.09.015.

Chen, F., and J. Dudhia, 2001: Coupling and advanced landsurface/hydrology model with the Penn State /NCAR MM5 modeling system. Part I: Model implementation and sensitivity. Mon. Wea. Rev., 129, 569-585, https://doi.org/10.1175/ 1520-0493(2001)129<0569:CAALSH > 2.0.CO;2.

_ and Coauthors, 2011: The integrated WRF/urban modelling system: Development, evaluation, and applications to urban environmental problems. Int. J. Climatol., 31, 273-288, https:// doi.org/10.1002/joc.2158.

Clarke, J. A., P. P. Yaneske, and A. A. Pinney, 1991: The harmonization of thermal properties of building materials. BEPAC Tech. Note 91/6, 87 pp.

Cui, Y.-Y., and B. De Foy, 2012: Seasonal variations of the urban heat island at the surface and the near-surface and reductions due to urban vegetation in Mexico City. J. Appl. Meteor. Climatol., 51, 855-867, https://doi.org/10.1175/JAMC-D-11-0104.1.

Dudhia, J., 1989: Numerical study of convection observed during the winter monsoon experiment using a mesoscale two-dimensional model. J. Atmos. Sci., 46, 3077-3107, https://doi.org/10.1175/ 1520-0469(1989)046<3077:NSOCOD > 2.0.CO;2.

Fry, J., and Coauthors, 2011: Completion of the 2006 National Land Cover Database for the conterminous United States. Photogramm. Eng. Remote Sens., 77, 858-864.

Georgescu, M., 2015: Challenges associated with adaptation to future urban expansion. J. Climate, 28, 2544-2563, https:// doi.org/10.1175/JCLI-D-14-00290.1.

_- M. Moustaoui, A. Mahalov, and J. Dudhia, 2011: An alternative explanation of the semiarid urban area "oasis effect." J. Geophys. Res., 116, D24113, https://doi.org/10.1029/ 2011JD016720.

— - B. G. Morefield, B. G. Bierwagen, and C. P. Weaver, 2014: Urban adaptation can roll back warming of emerging megapolitan regions. Proc. Natl. Acad. Sci. USA, 111, 2909-2914, https://doi.org/10.1073/pnas.1322280111.

Janjić, Z. I., 1994: The step-mountain eta coordinate model: Further developments of the convection, viscous sublayer, and turbulent closure schemes. Mon. Wea. Rev., 122, 927-945, https://doi.org/ 10.1175/1520-0493(1994)122<0927:TSMECM > 2.0.CO;2.

Kusaka, H., and F. Kimura, 2004: Thermal effects of urban canyon structure on the nocturnal heat island: Numerical experiment using a mesoscale model coupled with an urban canopy model. J. Appl. Meteor., 43, 1899-1910, https://doi.org/10.1175/ JAM2169.1.

Li, D., E. Bou-Zeid, and M. Oppenheimer, 2014: The effectiveness of cool and green roofs as urban heat island mitigation strategies. Environ. Res. Lett., 9, 055002, https://doi.org/10.1088/ 1748-9326/9/5/055002.

Martilli, A., A. Clappier, and M. W. Rotach, 2002: An urban surface exchange parameterization for mesoscale models. Bound.-Layer Meteor., 104, 261-304, https://doi.org/10.1023/ A:1016099921195.

Mlawer, E. J., S. J. Taubman, P. D. Brown, M. J. Iacono, and S. A. Clough, 1997: Radiative transfer for inhomogeneous atmospheres: RRTM, a validated correlated-k model for the longwave. J. Geophys. Res., 102, 16 663-16 682, https://doi.org/ 10.1029/97JD00237.

Niu, G.-Y., and Coauthors, 2011: The community Noah land surface model with multiparameterization options (Noah-MP): 1 .
Model description and evaluation with local-scale measurements. J. Geophys. Res., 116, D12109, https://doi.org/10.1029/ 2010JD015139.

Oke, T. R., 1988: Boundary Layer Climates. 2nd ed. Routledge, $464 \mathrm{pp}$.

Oleson, K. W., G. B. Bonan, and J. Feddema, 2010: Effects of white roofs on urban temperature in a global climate model. Geophys. Res. Lett., 37, L03701, https://doi.org/10.1029/2009GL042194.

Salamanca, F., A. Martilli, M. Tewari, and F. Chen, 2011: A study of the urban boundary layer using different urban parameterizations and high-resolution urban canopy parameters with WRF. J. Appl. Meteor. Climatol., 50, 1107-1128, https:// doi.org/10.1175/2010JAMC2538.1.

, M. Georgescu, A. Mahalov, and M. Moustaoui, 2015: Summertime response of temperature and cooling energy demand to urban expansion in a semiarid environment. J. Appl. Meteor. Climatol., 54, 1756-1772, https://doi.org/10.1175/JAMC-D-14-0313.1.

,,,$--- \ldots$, and A. Martilli, 2016: Citywide impacts of cool roof and rooftop solar photovoltaic deployment on near-surface air temperature and cooling energy demand. Bound.-Layer Meteor., 161, 203-221, https://doi.org/10.1007/ s10546-016-0160-y.

_ , Y. Zhang, M. Barlage, F. Chen, A. Mahalov, and S. Miao, 2018: Evaluation of the WRF-urban modeling system coupled to Noah and Noah-MP land surface models over a semiarid urban environment. J. Geophys. Res. Atmos., 123, 2387-2408, https://doi.org/10.1002/2018JD028377.

Skamarock, W. C., and Coauthors, 2008: A description of the Advanced Research WRF version 3. NCAR Tech. Note NCAR/TN-475+STR, 113 pp., https://doi.org/10.5065/ D68S4MVH.

Sun, C.-Y., A. J. Brazel, W. T. L. Chow, B. C. Hedquist, and L. Prashad, 2009: Desert heat island study in winter by mobile transect and remote sensing techniques. Theor. Appl. Climatol., 98, 323-335, https://doi.org/10.1007/s00704-009-0120-2.

Tewari, M., F. Salamanca, A. Martilli, L. Treinish, and A. Mahalov, 2017: Impacts of projected urban expansion and global warming on cooling energy demand over a semiarid region. Atmos. Sci. Lett., 18, 419-426, https://doi.org/10.1002/asl.784.

Trigo, I. F., S. Boussetta, P. Viterbo, G. Balsamo, A. Beljaars, and I. Sandu, 2015: Comparison of model land skin temperature with remotely sensed estimates and assessment of surfaceatmosphere coupling. J. Geophys. Res. Atmos., 120, 12 09612 111, https://doi.org/10.1002/2015JD023812.

United Nations, Department of Economic and Social Affairs, Population Division 2015: World urbanization prospects: The 2014 revision. Tech. Rep. ST/ESA/SER.A/366, United Nations, 517 pp.

Vahmani, P., F. Sun, A. Hall, and G. Ban-Weiss, 2016: Investigating the climate impacts of urbanization and the potential for cool roofs to counter future climate change in Southern California. Environ. Res. Lett., 11, 124027, https:// doi.org/10.1088/1748-9326/11/12/124027.

Wan, Z., Y. Zhang, Q. Zhang, and Z.-L. Li, 2004: Quality assessment and validation of the MODIS global land surface temperature. Int. J. Remote Sens., 25, 261-274, https://doi.org/ 10.1080/0143116031000116417.

Yang, Z. L., and Coauthors, 2011: The community Noah land surface model with multiparameterization options (Noah-MP): 2. Evaluation over global river basins. J. Geophys. Res., 116, D12110, https://doi.org/10.1029/2010JD015140.

Zhao, D., and J. Wu, 2017: Contribution of urban surface expansion to regional warming in Beijing, China. J. Appl. Meteor. Climatol., 56, 1551-1559, https://doi.org/10.1175/JAMC-D-17-0019.1. 